\title{
The impact of antisperm antibodies on human male reproductive function: an update
}

\author{
Andreia Filipa Silva1,2, João Ramalho-Santos ${ }^{1,3}$ and Sandra Amaral1,4 \\ ${ }^{1}$ CNC-Center for Neuroscience and Cell Biology, CIBB, University of Coimbra, Coimbra, Portugal, ${ }^{2}$ PhD Programme \\ in Experimental Biology and Biomedicine (PDBEB), Institute for Interdisciplinary Research (IIIUC), University of \\ Coimbra, Coimbra, Portugal, ${ }^{3}$ Department of Life Sciences, University of Coimbra, Coimbra, Portugal and ${ }^{4}$ Institute \\ for Interdisciplinary Research (IIIUC), University of Coimbra, Coimbra, Portugal
}

Correspondence should be addressed to S Amaral; Email: scgamaral@gmail.com

\begin{abstract}
Immune infertility occurs due to the presence of antisperm antibodies (ASA). This type of infertility has a relatively low prevalence (2.6-6.6\% in infertile men), and its etiology, risk factors, targets, and consequences for male fertility are not completely understood. While it is largely accepted that abnormalities in the blood-testis barrier and/or blood-epididymal barrier are the main factors behind its etiology, and that sperm motility is the most frequently reported altered parameter, few are the well-defined risk factors and ASA targets only now started to be disclosed, with proteins involved in sperm-oocyte interaction rising as the most significant. The development of potential treatments is also limited, being the corticosteroids the more promising. Overall, there are still many knowledge gaps related to immune infertility. With this review, we aimed to gather all the information collected from studies developed in humans in the last decade. Despite the controversial results/inconsistencies, that are not only a result of the complexity of mechanisms/variables involved in ASA infertility but also from the technical approaches to assess ASA and the lack of a consensus regarding the thresholds to be used, this manuscript aims to bring a fresh update on the field. It has become clear that, to obtain more/reliable data, there is a need to assess ASA in all the routine seminal analyses, following WHO recommendations. In this way, it will be possible to obtain consistent and comparable information, that can add to current knowledge. Additionally, multicentric studies with large cohorts are also missing, and future research should take this into consideration.

Reproduction (2021) 162 R55-R71
\end{abstract}

\section{Introduction}

Infertility is a disease of the reproductive system considered by the World Health Organization (WHO) as a global health issue affecting millions of people at reproductive age. This disease may occur due to both male and female factors, a combination of both, or even due to unexplained reasons (Dohle et al. 2010, WHO 2010, Jungwirth et al. 2019).

Of the several causes of male infertility, the presence of antisperm antibodies (ASA) leads to so-called immune infertility, an autoimmune disease of the reproductive system with low documented prevalence (Bohring \& Krause 2003, Dohle et al. 2010, Cui et al. 2015, Jungwirth et al. 2019). Antisperm antibodies are immunoglobulins that interact with sperm antigens, hindering the function of the male gamete, and thus playing a role in fertility (Azizi et al. 2015). In fact, it has been described that the presence of these antibodies can be involved in male fertility impairment (Zini et al. 2010, Bozhedomov et al. 2014a, 2015, Verón et al. 2016, Al-Daghistani 2020). However, the complexity of each individual human body has provided a challenge for research in several areas, and the theme of immunological infertility due to the presence of ASA is not an exception, mainly due to the inherent heterogeneity of human semen samples (Sousa et al. 2011).

The aim of this review is thus to provide an overview of the research studies focusing on ASA that were published during the last decade, structured in relevant sections that offer readers an overall state of the art on this issue, in an attempt to clarify what the currently relevant knowledge on this subject actually is, highlighting gaps of information and contradictions, and, finally, shedding some light on what the research on this topic should be in the future.

For this purpose, all the accessible studies performed in humans and written in English found in the PubMed database from 2010 to the end of 2020 were considered, when the search was made using 
the keywords 'antisperm antibodies'. Papers that had several flaws in terms of the concept, experimental design, and/or results expression as well as studies in the female part were excluded. In the same way, whenever justified, papers before 2010 and reviews were included (Fig. 1 and Supplementary Table 1, see section on supplementary materials given at the end of this article).

The first reported studies on PubMed when the search is made using the keyword 'antisperm antibodies' dated from the early 1960s (Fig. 2). However, it is well accepted that the human ASA research journey started in 1954 (Vazquez-Levin et al. 2014, Cui et al. 2015, Wakimoto et al. 2018) with the studies of Rumke (Rumke 1954) and Wilson (Wilson 1954), in which they showed that antibody activity can lead to sperm agglutination and immobilization in the blood (Rumke 1954, Wilson 1954) and seminal plasma (Wilson 1954) in a specific group of men with fertility problems.

Thereafter, the interest in this topic began to increase from the 1970s onwards, reaching a peak in terms of the number of PubMed publications between the late 1980s and early 1990s (Fig. 2). Afterward, the attention in this field starts to decrease, with a constant decline in the published articles in the last 2 decades (Fig. 2). The reasons for such disinterest may be due to the

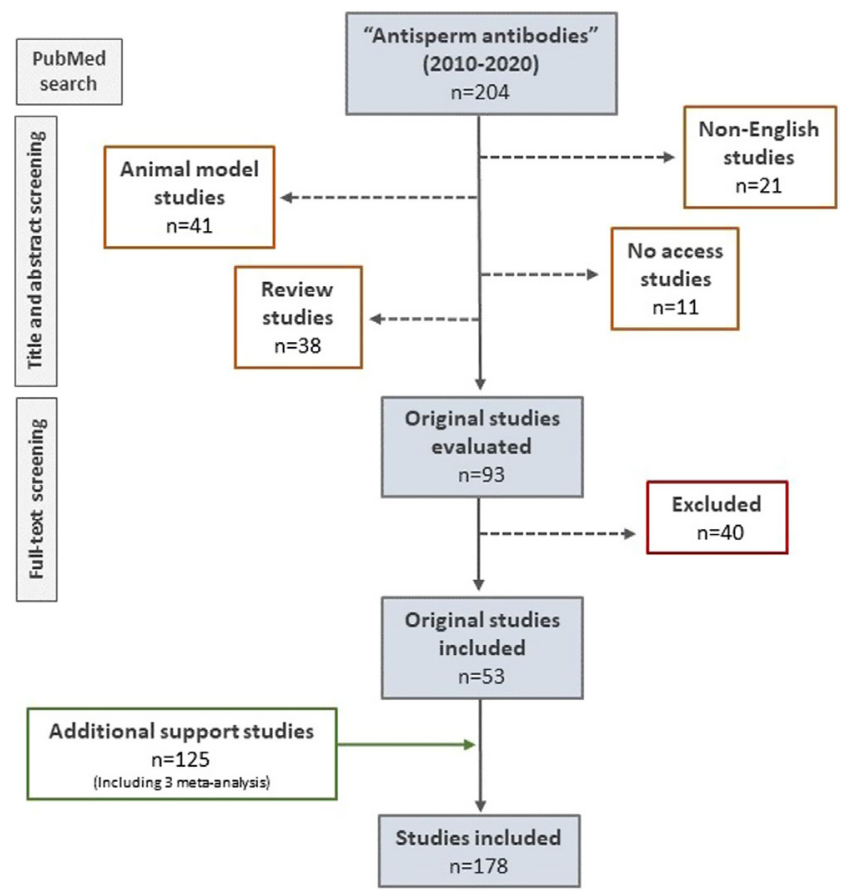

Figure 1 Flow diagram of the studies selection criteria. From the initial 204 studies (initial PubMed search), only studies in humans were included. Furthermore, reviews, non-English and with no access studies were excluded. After full-text screening, and considering support manuscripts, 178 studies were included in this review. lack of consistency in the experimental design and methodologies employed, as well as the frequently contradictory results reported.

Despite all the discouraging contradictions that were found during the early years of intense research, systematic reviews and meta-analysis on these issues are scarce. In fact, only a couple of studies started to appear in the last decade. More precisely, six systematic reviews come out (Zini et al. 2011a, Cui et al. 2015, Foresta et al. 2015, Jiang et al. 2016, Tiseo et al. 2016, Patel et al. 2018), in which only half of them includes a consistent meta-analysis (Zini et al. 2011a, Cui et al. 2015, Jiang et al. 2016). Considering the contradictory results obtained through the years, the number of this type of rigorous and compilatory studies, that have the power to identify strengths and weaknesses of the existing studies and eventually improve further research, are frankly insufficient, which once again is reflected in the current disinterest on the topic.

With the upcoming 6th edition of the WHO manual for semen analysis, perhaps more andrology and research centers may become WHO associated laboratories, contributing with their expertise and knowledge, and delivering new and more reliable data, in a global effort to research aspects that are not yet fully understood regarding ASA-related male infertility.

\section{Antisperm antibodies etiology}

Despite its potentially high relevance, it is not currently possible to clearly state that the etiology of ASA has been fully characterized. It is generally accepted that developmental abnormalities in the blood-testis barrier (BTB) formation as well as its weakness, damage, and/or disruption can lead to the appearance of ASA (Chamley \& Clarke 2007, Azizi et al. 2015, Brincat et al. 2015, Xu et al. 2020) due to the exposure of immunogenic sperm antigens to immunocompetent cells from the immune system (Mazumdar \& Levine 1998). In fact, some conditions which are associated, at least to some extent, with the integrity of the $\mathrm{BTB}$, and can also be possible risk factors for ASA development as we will further discuss, have gained attention in the study of ASA-mediated male infertility. Additionally, although not so explored, it is also possible that ASA may be produced at the epididymal level (Lotti et al. 2018). In fact, the blood-epididymal barrier (BEB) protects the epididymis and regulates the luminal microenvironment allowing sperm maturation and storage. In the same way, the loss of BEB function/ integrity, believed to be less robust than BTB, can more easily expose the sperm cells to the immune system resulting in ASA production (Hedger 2011, Lotti et al. 2018). However, in the vast majority of cases, the generation of naturally occurring ASA seems to have an idiopathic origin (Barbonetti et al. 2019). 


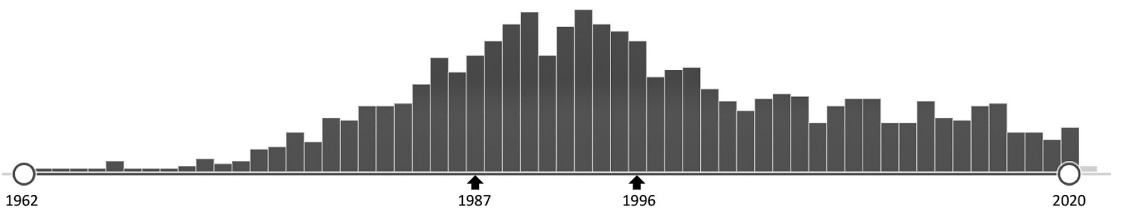

Figure 2 Graphic representation of the distribution of ASA studies throughout the years. This information was assessed at the PubMed database when the search was made using the keywords 'antisperm antibodies'. The publications in this field peaked in the time interval represented between the two arrows. Source: https://pubmed.ncbi.nlm.nih.gov/ (accessed on 20 January 2021).

\section{Types of antisperm antibodies and their clinical relevance}

In men, antisperm antibodies can be found in the blood serum and also in seminal plasma both free and bound to the surface of the sperm cell (Cui et al. 2015). They are immunoglobulins against the sperm cell which belong almost exclusively to the class $G$ and A, namely $\lg G$ and $\lg A$, respectively (WHO 2010, Vazquez-Levin et al. 2014). Both immunoglobulin classes can be detected on the surface of the sperm cells or in biological fluids (WHO 2010). Nevertheless, the principal immunoglobulin found in the blood belongs predominantly to the IgG isotype while those found in external secretions, such as the seminal plasma or even the cervical mucus in women, are mostly from the $\lg A$ isotype (Schroeder \& Cavacini 2010). The IgA isotype, found at the mucosal surfaces and secretions, has an essential role in the protection from several external agents such as toxins, virus, or bacteria (Schroeder Jr \& Cavacini 2010), and this is the reason why this type of antibodies may assume more clinical importance than IgG antibodies (Kremer \& Jager 1980, WHO 2010). The targets of these IgG and IgA-ASA are now starting to be disclosed, yet the knowledge is still limited as we will discuss later in this manuscript (see 'Antisperm antibodies targets' section).

\section{Detection of antisperm antibodies}

The World Health Organization has recommended the testing for antisperm antibodies as a 'standard procedure' referring to the event of sperm agglutination as a possible indicator of the presence of ASA. Nevertheless, it also notes that agglutination can be caused by factors other than ASA as well as the fact that ASA may be present even without sperm agglutination (WHO 1999, 2010). In our understanding, these recommendations highlight the necessity of routine test for ASA. From a research point of view, the testing of ASA is crucial to gather relevant data regarding ASA-associated fertility problems. However, these tests are not systematically recommended, even in WHO-associated laboratories, unless specific indicative conditions are present, as is the case of sperm agglutination. Nonetheless, Gatimel and co-workers further suggest the history of scrotal trauma or inguinal surgery, as significant factors to justify the testing for ASA (Gatimel et al. 2018). Yet, a consensus about the exact situations in which tests should be performed is lacking (Lu et al. 2010, Gatimel et al. 2018).

Considering the methodologies to detect ASA, since 1999 that WHO has recommended the use of both direct and indirect tests to detect the presence of $\lg G$ and $\lg A$ (WHO 1999, 2010). The direct tests, which detect ASA on the surface of motile sperm cells are widely used and comprise the mixed antiglobulin reaction (MAR) test and the immunobead (IB) test. Both of them are well described in the last editions of the WHO manual (WHO 1999, 2010) and despite their similarities, they present important differences that should not be neglected. While the MAR test entails the use of fresh semen samples, the IB test should be performed in washed samples (WHO 1999, 2010). Due to its application in unwashed fresh samples and the possible use of treated erythrocytes as beads, which makes it faster and cheaper (WHO 1999, 2010), the MAR test is the most routinely used in the andrology laboratories (Gatimel et al. 2018). Additionally, it is important to remark that the IB test was recently curtailed by the manufacturer, and a progressive replacement of this test by the new immunosphere (IS) test is expected. This new IS test is similar to the IB test considering the concept and execution and also shows a good correlation with the former IB test (Bollendorf \& Check 2016).

When necessary or when it is not possible to perform the direct tests, for example, due to a high percentage of immotile sperm cells in the sample, WHO suggests the use of indirect tests. The indirect tests can detect ASA in heat-inactivated sperm-free fluids as is the case of blood serum, testicular fluid, seminal plasma, or even solubilized cervical mucus, using for this purpose antibody-free donor spermatozoa following the direct IB test mentioned above (WHO 1999, 2010).

On the other hand, considering the good specificity and the quantitative power of the enzyme-linked immunosorbent assay (ELISA; Mazumdar \& Levine 1998), this serological test is also broadly accepted in the screening of blood serum ASA (Lu et al. 2010), probably because it bypasses the complexity and slowness of the indirect tests recommended by the $\mathrm{WHO}$. There are also other indirect tests, such as the tray agglutination test (TAT), gelatin agglutination test (GAT), and sperm immobilization test (SIT; Gandini et al. 1995, 
Naz \& Butler 2013), that were quite used in the past but nowadays are not so common.

Overall, the direct MAR and IB tests along with ELISA are the first line of choice tests for ASA screening, both in semen and serum. However, the results obtained from the different methodologies (Xu et al. 2020) and between the different commercially available kits (Lu et al. 2019) are not always consistent. In fact, based on studies developed during the 1980s, the WHO reported the fact that the results obtained from MAR and IB tests do not always match (MacMillan \& Baker 1987, Scarselli et al. 1987, Meinertz \& Bronson 1988, Hellstrom et al. 1989). Also, a relatively recent report from a survey in China concluded that the methods of semen analysis, as well as results interpretation among laboratories, have marked differences, with several of these laboratories working with other methods than those recommended by the WHO (Lu et al. 2010). Therefore, the standardization of ASA detection among laboratories worldwide seems to be urgent.

The recently validated protein biochip, a microarraybased technology, which takes advantage of the highthroughput methodology with minimal input of sample and providing extremely high sensitive and specific results, has shown significant consistency with ELISA in serum ASA detection (Wang et al. 2017, Xu et al. 2020). In addition, the results obtained with the MAR test were also comparable with the biochip approach (Xu et al. 2020). This type of technology was, therefore, suggested as an important tool for the screening of ASA in serum in large cohorts of patients (Wang et al. 2017, Xu et al. 2020).

Additionally, there are authors that have used flow cytometry as this technique allows the quantification of IgG and/or IgA levels in each live sperm cell (Haas \& Cunningham 1984, Räsänen et al. 1992), which is an upgrade of the immunofluorescence assays that also use fluorescein-tagged anti-human antibodies to detect ASA but it has to be performed in fixed samples (Helmerhorst et al. 1999). Nonetheless, this method has not gained a special relevance.

When it comes to the threshold used to consider ASA levels pathological, $\mathrm{WHO}$ recommends $50 \%$ motile spermatozoa with adherent particles (WHO 1999, 2010). However, the use of different methodologies to detect ASA, along with differences in thresholds for ASA positivity among the research works, make comparisons between studies hard to accomplish (Supplementary Table 1). Among the $\mathrm{WHO}$ recommended tests (MAR test and IB test), the expression of the obtained results is made in percentage (\%) of cells while in the case of the ELISA assays, the results are given using the international units (IU) for enzymatic assays, making them difficult to compare. Another example of this difficulty is the case of the already mentioned biochip technology, in which the results are expressed in fluorescent optical density (FOD), highlighting one of the major limitations in the interpretation of studies focusing on ASA-related male infertility.

In fact, while in the ELISA method, the definition of the thresholds is relatively easy to follow and supported by several studies in which comparisons with the results obtained by WHO recommended tests were done for many years, the most recent technologies, as the case of the biochip approach, do not have this support, and the results are more difficult to understand. These aspects might also justify some of the contradictions found in the literature, stressing the need to homogenize the tests used to assess ASA worldwide.

\section{Antisperm antibodies prevalence}

Differences in the occurrence of ASA directly derive from the testing method and obviously from the cut-off definition used (Vazquez-Levin et al. 2014, Verón et al. 2016, Barbonetti et al. 2019). Furthermore, some of the available results were not obtained in a clinical setting, where theoretically, the types of tests used to detect ASA and the cut-off value for ASA positivity are well established by the WHO. This fact leads to significant differences in terms of the percentage of positive ASA samples among distinct research cohorts and a lack of consistency considering the prevalence of this specific group of patients.

Another confounding aspect is the fact that the incidence of ASA is also affected by changes in the WHO criteria for seminal quality throughout the years. Although the threshold value for ASA positivity was maintained unaltered in the last two editions, the same was not verified for the reference levels for seminal quality (WHO 1999, 2010). This detail means that, based on the spermiogram results, patients that were considered to have poor parameters according to the 1999 criteria, might be considered normal according to the WHO 2010 edition since in 2010, there was a decrease in the reference levels limit (Jensen et al. 2018). This suggests that probably before 2010 more patients were being screened for ASA than now. We hope that the upcoming 6th edition of the WHO manual for semen analysis can definitely help to mitigate these differences. Additionally, several other factors can contribute to the variability of the reported prevalence of these antibodies, such as sample size and the experience of the lab technician that is performing the test, among others.

As expected, the incidence of ASA varies between fertile and infertile men, with the reported percentages associated with fertile men being much lower than the ones reported in the infertile patients (Zini et al. 2011a, Cui et al. 2015). Yet, the available data in the fertile group are scarce since these individuals are not extensively studied, and here we need to highlight again that the two existing WHO manuals for semen analysis might play a role. During the last decade, two meta-analyses reported similar results regarding the prevalence of ASA 
in infertile and fertile men (Zini et al. 2011a, Cui et al. 2015) with significant levels of ASA detected in the semen of $5-15 \%$ of infertile men (Adeghe 1993, Collins et al. 1993, Sinisi et al. 1993) but only in 1-2\% of fertile ones (Sinisi et al. 1993, Bates 1997).

Based on the most relevant and recent literature, we noticed a mean ASA prevalence among the infertile male population between 2.6 and $6.6 \%$ (Table 1). For this, we considered four studies that used the direct MAR test methodology and the $50 \%$ threshold for positivity given by the WHO (Verón et al. 2016, Gatimel et al. 2018, Lotti et al. 2018, Barbonetti et al. 2019). Among these research works, there is a recent and wide retrospective study of over 10,000 men that certainly provides a consistent contribution (Barbonetti et al. 2019). Also, in one of the studies guided by the same criteria, the ASA incidence among a cohort of fertile men $(0.9 \% ; n=109)$ was also reported (Lotti et al. 2018), and this percentage is in accordance with the oldest studies mentioned above (Zini et al. 2011a, Cui et al. 2015).

Interestingly, using the biochip technology and the ELISA methodology, the percentages of ASA prevalence found in serum seem to be quite higher when compared with those obtained on the sperm surface using the direct MAR test (Table 2; Lu et al. 2019, Xu et al. 2020). In fact, although these types of technologies have the advantage of being more sensitive, comparisons are difficult to make since the direct MAR test measures the sperm cell surface ASA, while the others detect free ASA in the blood serum. Nonetheless, considering biochip technology, there was a study in which the results were comparable with that obtained by ELISA and MAR test methods (Table 2; Xu et al. 2020), although in this case, the prevalence determined by the MAR and ELISA tests were higher compared to previous studies (Verón et al. 2016, Gatimel et al. 2018, Lotti et al. 2018, Barbonetti et al. 2019, Lu et al. 2019).

\section{Antisperm antibodies effects on fertility}

Antisperm antibodies may affect male fertility in several ways. The most documented effects are their capacity to reduce sperm motility, cause sperm agglutination, impair sperm ability to penetrate the cervical mucus, or inhibit sperm capacitation, the acrosome reaction, sperm-egg interaction, as well as the initial stages of

Table 1 Prevalence of sperm-bound ASA among infertile men assessed by the direct MAR test and using a 50\% cut-off for ASA positivity (WHO 2010).

\begin{tabular}{lcc}
\hline Reference & Samples $(n)$ & $\begin{array}{c}\text { Prevalence among } \\
\text { infertile men }(\%)\end{array}$ \\
\hline Barbonetti et al. (2019) & 10,025 & 3.4 \\
Gatimel et al. (2018) & 1364 & 4.4 \\
Lotti et al. (2018)* & 181 & 6.6 \\
Verón et al. (2016) & 7492 & 2.6 \\
\hline
\end{tabular}

*Study also reports $0.9 \%$ prevalence among fertile men $(n=109)$.

ASA, antisperm antibodies; MAR, mixed antiglobulin reaction.
Table 2 Prevalence of blood serum ASA among infertile men assessed by protein biochip and ELISA methodologies.

\begin{tabular}{lcccc}
\hline & & \multicolumn{3}{c}{ Prevalence among infertile men $(\%)$} \\
\cline { 3 - 5 } Reference & Samples $(n)$ & $\begin{array}{c}\text { Protein } \\
\text { biochip* }\end{array}$ & ELISA & MAR \\
\hline Xu et al. (2020) & 368 & 20.92 & $21.47^{\#}$ & $16.03^{\ddagger}$ \\
Lu et al. (2019) & 554 & & $10.5+$ & \\
\hline
\end{tabular}

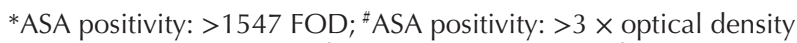
(OD) of negative controls; ${ }^{\dagger}$ ASA positivity: $>75 \mathrm{IU} ;{ }^{\ddagger} n=262$.

ASA, antisperm antibodies; FOD, fluorescent optical density; MAR, mixed antiglobulin reaction.

embryo development (Sinisi et al. 1993, Nagy et al. 1995, Mazumdar \& Levine 1998, Lombardo et al. 2001, Francavilla \& Barbonetti 2009, Krause 2009, Zini et al. 2010, Bozhedomov et al. 2015, Verón et al. 2016, Al-Daghistani 2020). Additionally, although not so unanimous, other parameters such as sperm count, morphology, and viability also seem to be prone to alterations in this specific group of patients (Zini et al. 2010, Štula et al. 2012, 2014, Cui et al. 2015, Verón et al. 2016).

The conventional seminal analysis (motility, morphology, concentration) is widely used by clinicians and researchers to categorize the type of male infertility when no other clinical alterations are reported. Motility has gained particular importance in ASA since effects are immediately observable and easily quantified. It is definitely the most accepted altered parameter when it comes to the negative effects of the presence of ASA.

Furthermore, as male infertility is already known to be associated with sperm DNA damage (Evenson et al. 1999, Zini \& Sigman 2009), it was also possible that a poor DNA integrity may be a consequence of ASA presence and, therefore, an indirect cause of infertility in ASA patients. However, the results regarding this topic are conflicting, and if on one hand there is a study that does not confirm this hypothesis (Zini et al. 2010), another one showed an increase in DNA fragmentation in ASA patients along with an increase in sperm reactive oxygen species (ROS) generation (Bozhedomov et al. 2015).

Although some doubts and questions still persist, overall, it seems that the presence of ASA may affect male fertility in several ways. Sometimes reducing seminal quality, others impairing steps in the fertilization process, or even a combination of both, but it is also a truth that ASA does not always cause fertility problems, so its relevance to the global male infertility panorama should be re-evaluated. The nature of the ASA targets is now starting to be disclosed. Although the relevance of the proteins identified so far is not always straightforward, it is expected that full and integrated characterization at a molecular level will provide the necessary knowledge to better diagnose ASA-mediated immunoinfertility and eventually to tailor the treatment to these patients. 


\section{Possible risk factors for antisperm antibodies}

\section{Vasectomy}

Vasectomy is a surgical procedure for male sterilization in which both vas deferens are cut or sealed. This type of procedure can lead to an immunogenic response thus initiating the production of ASA (Marconi \& Weidner 2017). The association between vasectomy and ASA production is well documented (Gubin et al. 1998, Marconi et al. 2008, Lee et al. 2009, Azizi et al. 2015). In fact, this is one of the most accepted risk factors associated with ASA generation (Marconi \& Weidner 2017). Additionally, it was recently reported that the predisposition for ASA production in vasectomized men seems to be associated with some molecules of the human leukocyte antigen (HLA) system, with men having lower serum ASA levels presenting specific HLA antigens, such as HLA-A2, HLA-B5, HLA-DR53, and HLA-DQ2 (Azizi et al. 2015). However, the threshold that used to define ASA positivity was not mentioned (Supplementary Table 2), and the relationship between HLA antigens and ASA production requires additional research since a strong association between other HLA antigens (HLA-A28) with ASA production after vasectomy was also reported (Law et al. 1979).

On the other hand, sometimes vasectomized men seek vasectomy reversal surgery, and it is possible that elevated ASA can lead to limited success in fertility recovery. In fact, after vasectomy reversal, an increase in serum ASA levels was observed to be associated with the BMI (overweight and obese) of the studied individuals but, as referred by the authors, the value of this finding is not clear; yet, no association was found between the serum ASA levels and fertility outcomes (Hinz et al. 2010). This study has also crucial points that were not mentioned, as is the case of the method to quantify ASA and the threshold used (Supplementary Table 2).

\section{Infection and inflammation}

The role of inflammatory processes in the male genital tract in the development of ASA has also been controversial (Krause \& Naz 2009, Marconi et al. 2009).

For example, regarding the prostate, it is known that the occurrence of an infection and inflammation is associated with prostatitis and may also be implicated in both benign prostatic hyperplasia and prostate cancer scenarios (Naz 1997, Kramer et al. 2007, Coussens \& Werb 2002). However, the most recent report on this topic has found no association between these prostate conditions and the induction of ASA formation (Hoover \& Naz 2012). Additionally, these types of prostate disorders lead to an increase of circulating prostatespecific antigen (PSA), which is a serine protease produced by the prostate gland and secreted into the seminal fluid with the main function of dissolving the seminal coagulum allowing sperm to swim freely ( $\mathrm{Naz}$
\& Butler 2013). However, there is no evidence of a concomitant induction of immunity to spermatozoa when a PSA rise is observed due to these prostate disorders (Hoover \& Naz 2012).

Interestingly, in a group of ASA-positive immunoinfertile men without any prostate disorder, an increase of seminal plasma PSA antibodies was reported (Cuppett et al. 2017) and similar observations had already been obtained in a different study, but in the sera of immunoinfertile men, although there the results did not reach statistical significance (Naz \& Butler 2013). Considering the main function of PSA in the liquefaction of seminal coagulum, it is expectable that the presence of antibodies against PSA in the seminal plasma may interfere with the fertilization process. However, for these authors, the mechanisms that lead to the production of PSA antibodies in ASA-positive immunoinfertile men are unclear and whether these PSA antibodies are the causative factor of infertility or just associated with it require further investigations (Naz \& Butler 2013, Cuppett et al. 2017). Nonetheless, these studies are an example of those that use a different threshold for ASA than the one recommended by $\mathrm{WHO}$; in this case, they refer that positivity is $20 \%$, very low considering the WHO criteria of $50 \%$, and it is, therefore, difficult to compare with other works and to hypothesize about the possible role of PSA antibodies in this type of infertility (Supplemental Table 2).

In an orchitis scenario, which is an inflammation of the testis, the most recent data did not find any association between ASA development and previous orchitis (Yasin et al. 2016, Lu et al. 2019). However, the existing works did not explore this condition properly, and only enrolled a few patients.

Moreover, in a recent study, interesting new aspects were identified in ASA-positive infertile patients as is the case of epididymal abnormalities, history of epididymitis, and high levels of the marker of genital tract inflammation, seminal plasma interleukin 8 (sIL-8), but, surprisingly, not testicular alterations. These results reported by Lotti and collaborators, following the WHO guidelines for ASA positivity, are strongly suggestive of chronic epididymal inflammation in ASA-positive patients (Lotti et al. 2018). The authors suggest that the epididymal function should be, therefore, studied in ASA-positive patients. However, in this study, the authors did not observe any correlation of epididymal alterations with seminal parameters, and this aspect should be further explored in further studies.

\section{Viral infections}

Seminal infections are widely accepted as a significant contributor to male infertility (Ochsendorf 2008, Rusz et al. 2012). Although these infections may trigger autoimmune reactions accompanied by inherent ASA production (Witkin et al. 1995), the association of 
viral infections with ASA development has not been extensively studied. As a well-recognized cause of orchitis, mumps was the focus of some studies at the beginning of the 2000s (Kalaydjiev et al. 2001, 2002, Jarow 2002), that explored its consequences in terms of ASA production, however, not finding a clear association. During the last years, this question was only addressed in the cases of hepatitis $\mathrm{C}$ virus (HCV; Hussein et al. 2017), human papilloma virus (HPV; Garolla et al. 2013, 2018, Luttmer et al. 2016), and adeno-associated virus (AAV; Schlehofer et al. 2012).

Despite some differences between studies, the main finding and conclusion considering the context of a viral infection is the existence of a higher prevalence of ASA on the sperm surface, accompanied by a significant decrease in sperm motility (Garolla et al. 2013, 2018, Hussein et al. 2017). These findings were reported in HCV men (Hussein et al. 2017) as well as in HPV infertile men (Garolla et al. 2013) along with the decrease of ASA prevalence and motility improvement in the HPV vaccinated ones (Garolla et al. 2018). Although several recent findings suggest that viral infections could adversely contribute to the impairment of sperm motility through the development of ASA, contradictory results also exist, in which no association between the presence of both HPV (Luttmer et al. 2016) and AAV (Schlehofer et al. 2012) with seminal quality and ASA presence were reported. Although these studies present a suitable number of samples, the threshold for ASA positivity was not the same. While in the study of Garolla et al. (2013) the threshold for ASA positivity was defined according to the WHO criteria ( $\geq 50 \%)$, in other cases this threshold was $>10 \%$ (Hussein et al. 2017), $\geq 30 \%$ (Schlehofer et al. 2012), or not even mentioned (Luttmer et al. 2016, Garolla et al. 2018). These differences in ASA-positive group definition may lead to variations and, to some extent, explain some of the contradictions reported (Supplemental Table 2).

\section{Bacterial infections}

Seminal quality decline has been associated, by several authors, with the process of male genital tract infection and inflammation (Diemer et al. 2003) and, among bacterial pathogens, Chlamydia trachomatis was reported as the most sexually transmitted bacteria in industrialized countries (Johnson et al. 2002, EggertKruse et al. 2015). Thus, the majority of the studies on male seminal quality in the context of bacterial infection have been focused on Chlamydia trachomatis.

Curiously, a study that used next-generation sequencing technology and bioinformatics analysis to study all seminal bacterial communities and their association with seminal quality did not report the genus Chlamydia as one of the most abundant among samples, appearing only in a trace percentage. More than that, they do not mention Chlamydia in the genera associated with normal or abnormal seminal parameters, being Sphingobium the only genus significantly abundant in samples with abnormal clinical ASA value (Weng et al. 2014).

On the other hand, heat shock proteins (HSP) also known as chaperones seem to have a significant role since these proteins are released in response to stressful conditions, as is the case of infections (Martínez-Prado \& Camejo Bermúdez 2010, Naaby-Hansen \& Herr 2010). Besides that, the bacterial $60 \mathrm{kd}$ HSP family (bacterial HSP60), which are recognized as the major antigenic determinants during an infection, shares approximately $50 \%$ homology with human HSP60 (Shinnick 1991, Morrison et al. 1992). This fact can lead to cross-reactivity issues associated with the development of autoimmune and inflammatory diseases (Jones et al. 1993, Wick et al. 2004), which may result in reproductive failure through ASA generation (Eggert-Kruse et al. 2015). However, the most recent studies are not unanimous regarding the association between the presence of chlamydial HSP antibodies and the presence of ASA (Martínez-Prado \& Camejo Bermúdez 2010, Eggert-Kruse et al. 2015) with some authors reporting an association between them (Martínez-Prado \& Camejo Bermúdez 2010) in contrast to others (Eggert-Kruse et al. 2002, 2015).

In this context, the existence of molecular mimicry between sperm and bacteria leading to cross-reactivity issues between ASA in humans and bacterial antibodies has been reported. A sperm immobilization factor (SIF) isolated from a bacteria immobilizes both human spermatozoa and motile bacteria (Prabha et al. 2009) due to the existence of a common receptor for SIF on spermatozoa and bacteria, that was recently identified (Prabha et al. 2011). In this particular study, the authors advanced the possibility of intravaginal therapy using these receptors in an attempt to improve fertility (Prabha et al. 2011). Transposing to its relevance in the ASA context, they hypothesize that the existence of this crossreactivity of sperm antigens and exogenous antigens may be the trigger for ASA development (Prabha et al. 2011) which certainly deserves to be more widely studied.

\section{Varicocele}

Varicocele is a condition characterized by an abnormal enlargement and a tortuosity of the spermatic cord veins and it is a highly prevalent condition among men, that is often found during routine physical examinations but whose etiology and associated pathophysiological mechanism remain not fully understood (Agarwal et al. 2007, Lomboy \& Coward 2016). The available literature on the possible influence of varicocele on ASA formation, so far, is contradictory (Marconi \& Weidner 2017), ranging from studies reporting an association between both conditions (Golomb et al. 1986, Gilbert et al. 1989, Knudson et al. 1994, Isitmangil et al. 1999) to studies reporting that varicocele is not a risk factor for 
ASA production at all (Oshinsky et al. 1993, Heidenreich et al. 1994, Veräjänkorva et al. 2003). During the last few years, only two studies contributed to this topic, but no correlation was found between ASA generation and varicocele (Bozhedomov et al. 2014a, Lu et al. 2019). Nevertheless, there is evidence that ASA in patients who already suffer from varicocele can considerably impair sperm function (Bozhedomov et al. 2014a). Indeed, ASA-positive varicocele patients were reported to have lower sperm concentration, progressive motility, and normal morphology, when compared with patients with varicocele, but without ASA. Additionally, the acrosome reaction seems to be impaired in patients with both ASA and varicocele, but in this case, when compared with a fertile control group. Finally, these authors also found a positive correlation between the percentage of sperm immunization and DNA fragmentation rate as well as the production of sperm ROS in ASA-positive varicocele patients, compared with both ASA-negative varicocele ones and a fertile group (Bozhedomov et al. 2014a).

The controversy on this topic is necessarily extended to the benefits of the varicocele surgical treatment in the seminal parameters of varicocele patients who already have ASA. Bozhedomov and colleagues have shown an unfavorable prognosis of varicocele surgical repair in cases of an initial high percentage of ASA and also demonstrated that the surgery efficacy in varicoceleASA patients was lower compared with varicocele patients without ASA, translated by a decrease in the reproductive function reestablishment (Bozhedomov et al. 2014b). Despite these results, it was also suggested that the varicocelectomy should not be abandoned and the existence of pre-operative ASA treatment protocols should be considered to maximize surgery benefits in varicocele-ASA patients (Al-Adl et al. 2014, Bozhedomov et al. 2014b). Considering the possibility of ASA generation after varicocele surgical repair, recent reports did not find any association in semen (Bonyadi et al. 2013) and serum ASA levels (Yasin et al. 2016, Lu et al. 2019). In fact, to our knowledge, only one study reported an increase in serum ASA levels after varicocelectomy (Bonyadi et al. 2013).

\section{Cryptorchidism}

Cryptorchidism is a common and well-known congenital condition among infant boys. Characterized by the absence of one or both testis from the scrotum, this condition is a well-recognized cause of infertility (Chung \& Brock 2011).

Despite the contradictory results from earlier studies (Marconi \& Weidner 2017), the most recent efforts did not show any associations between pre-puberty cryptorchidism (Imamoğlu et al. 2012, Jiang \& Zhu 2013a) or orchidopexy (Jiang \& Zhu 2013a) and the presence of ASA. At a genetic level, no differences were found among cryptorchidic patients in terms of
ASA positivity, notably in the natural killer cells surface receptors, which allow them to attack and kill abnormal cells as well as prevent them to attack the normal ones (Niepiekło-Miniewska et al. 2015). However, in terms of the human major histocompatibility complex class II HLA molecules, a surprising weak association of these genes and the predisposition to produce ASA among cryptorchidic pre-pubertal boys were described (Kurpisz et al. 2011). Nevertheless, the relevance of these observations requires further studies (Kurpisz et al. 2011).

\section{Inguinal hernia}

Inguinal hernia is a common medical condition that can be rapidly solved through a simple surgical procedure that may, however, potentially impact fertility. The current standardized surgical treatments are laparoscopic or open hernia repair being a mesh used in the majority of the cases (Scott et al. 2002, Sršen et al. 2008, Perko et al. 2011). In fact, it has been postulated that the reason for infertility issues in some of the cases could also be associated with immunological reactions derived from both the surgical procedures as well as the use of a mesh and the subsequent inflammatory process (Štula et al. 2012, Gupta et al. 2021).

The more recent literature has reported a significant increase in serum ASA levels from the pre- to postoperative situation in patients that underwent open (Stula et al. 2012, 2014, Krnić et al. 2016, Gupta et al. 2021) and urgent incarcerated (Krnić et al. 2016) hernia repair, although within the normal range values. Apparently, inguinal hernia repair does not lead to a clinically significant humoral autoimmune response (Marconi \& Weidner 2017). However, between the open and laparoscopic methods, the former seems to be the best option with a minimal increase in ASA levels (Štula et al. 2012, 2014, Gupta et al. 2021).

\section{Autoimmune diseases}

An autoimmune disease is a condition in which the immune system mistakenly produces antibodies that attack their own body's cells (NIEHS website: https://ww w.niehs.nih.gov/health/topics/conditions/autoimmune/ index.cfm accessed on 16 January 2021). Considering 'immune infertility' is also an autoimmune disease, it would be expectable that ASA could also be produced in association with other autoimmune conditions (Bohring \& Krause 2003). However, the last studies in this topic did not find any association between ASA presence (and also seminal quality and hormonal profiles) and autoimmune conditions, as is the case of primary antiphospholipid syndrome (Rabelo-Júnior et al. 2012) and ankylosing spondylitis (Nukumizu et al. 2012).

On the other hand, an antigen involved in the fertilization process (Busso et al. 2005) which was 
described as recognized by ASA, the cysteine-rich secretory protein (CRISP-2; Brunner-Agten et al. 2013), has shown structural similarities with the major wasp venom allergen (Ves v 5; Müller et al. 2008). The authors demonstrated that ASA-positive men had a higher incidence of allergy against Hymenoptera venom, and the results also showed a high amount of autoantibodies that cross-react with both CRISP-2 and Ves V 5 allergen. These autoantibodies lead to sperm immobilization and bind along the sperm surface, including the head, where CRISP-2 is localized (Brunner-Agten et al. 2013). Additionally, the fact that these autoantibodies can bind to Ves $V 5$ led the authors to hypothesize that ASA-positive men may have a higher risk to develop wasp allergy (Brunner-Agten et al. 2013). However, ASA positivity in this study was considered above $10 \%$ which is very different from the WHO reference value. This, together with the low number of individuals per experimental group, and the lack of discussion on the functional effects of ASA interaction with CRISP-2, that might actually compromise the fertilization process constitute some of the limitations of this study and therefore the value of the obtained results should be further explored and proven.

Finally, an association between programmed cell death 1 (PDCD1) gene polymorphism and ASA-related infertility was also suggested (Zamani et al. 2015). $P D C D 1$ has an immunoinhibitory function (Nishimura et al. 1999), and polymorphisms in this gene were already associated with several autoimmune diseases including rheumatoid arthritis (Lin et al. 2004), type I diabetes (Nielsen et al. 2003), multiple sclerosis (Kroner et al. 2005), ankylosing spondylitis (Lee et al. 2006), and allergies (James et al. 2005). In this particular study, a significant difference in the genotype and allele frequencies between ASA infertile patients and healthy controls was shown (Zamani et al. 2015). This study has, however, several crucial points that were not clear, as is the case of the method to quantify ASA and the threshold used (Supplemental Table 2), so one should be cautious in drawing any conclusions.

\section{Other factors}

Besides the supra-mentioned risk factors (often theoretically) associated with the presence of ASA, there are also some research studies that tried to disclose other risk factors associated with this ASA condition.

The production of ASA as a consequence of a vasectomy-induced immune response was suggested as a risk factor for primary progressive aphasia (PPA), language-based frontotemporal dementia, which is a type of primary dementia (Weintraub et al. 2006). Although the mechanisms involved in this association were not completely disclosed and are, in fact, difficult to understand, they are mainly based on some antigenic cross-reactivity between sperm and brain (Schachner et al. 1975, Chaffee \& Schachner 1978a,b), and the fact that the sperm is the only cell type, outside of the $\mathrm{CNS}$, that express the cytoskeletal tau protein, whose mutations are linked to familial dementia (Ashman et al. 1992). Nonetheless, in Alzheimer's disease, the most common cause of primary dementia, no association was found between the presence of serum ASA and cognitive or language dysfunction in elderly patients with this comorbidity (Han et al. 2010). However, the relevance of these studies in the context of male fertility seems to be minor.

Another study focused on a possible association between the testicular microlithiasis and ASA formation. Testicular microlithiasis is an uncommon pathological condition characterized by the deposition of multiple tiny calcifications throughout the testes with possible implications on the structure of the BTB. However, the authors concluded that this condition does not appear to be related with an elevated level of ASA in a cohort of infertile men (Jiang \& Zhu 2013b). Another hypothetic risk factor associated with a deleterious impact on the structure of the BTB is testicular sperm extraction (TESE) procedure, a common technique used for testicular sperm retrieval in cases of non-obstructive azoospermia (NOA), and several were the studies that focused on this aspect. Surprisingly, in terms of ASA development, only two studies were published, both concluding that TESE procedure does not lead to a significant increase of serum ASA levels (Komori et al. 2004, Ozturk et al. 2011). Children testicular rupture, a rare complication of testicular trauma, in which surgery is recommended due to the extrusion of the testicular contents, was also studied in the context of ASA production. However, no alterations were reported in the follow-up regarding the ASA levels after surgical repair (Pogorelić et al. 2011).

On the other hand, interesting data came out from another recent study focusing on the bedtime patterns (20:00-22:00 h, after 22:00 h, and after midnight) and duration (short, average, and long) of sleep in healthy men, showing an increase in ASA incidence in the short sleepers among all bedtime patterns (Liu et al. 2017). This study included 981 men and the authors attributed to ASA a role in the explanation of how sleep deprivation affects sperm health since they also found that short sleep duration impairs sperm count, viability, and motility (Liu et al. 2017). However, they did not suggest a possible mechanism to explain ASA generation in these men.

Overall, despite all the studies that were made over the years, the relevance of certain risk factors for the development of ASA is questionable. In fact, the multifactorial causes and consequences of infertilityrelated conditions, which can be considered ASA risk factors, along with the not-so-well understood ASA development mechanisms and the distinct research settings, including methodologies to detect ASA and thresholds used, have led to opposing conclusions that, in our opinion, are hindering the knowledge in the 
field of immune infertility (Supplemental Table 2). This undoubtedly highlights the need for further objective and systematic research on this subject to allow for more definitive conclusions.

\section{Antisperm antibodies targets}

The nature of the exact targets of ASA is the 1 million dollar question in this field, given that with this knowledge it would be possible to both better diagnose and treat ASA-mediated immunoinfertility, as well as to develop novel immunocontraceptive methods.

In fact, many studies have been focused on the identification of ASA targets, and several sperm antigens were already described in immunoinfertile ASA patients through the use of different types of methodologies, such as immunoprecipitation or different types of electrophoresis, nicely summarized by Vasquez-Levin et al. (2014). Some examples of these antigens include proteins involved in sperm-oolemma interaction (P18, P36, SLLP1 or SPRASA), zona pellucida binding proteins (NZ-2), among others in which the antigen function is unknown. The main difficulty in these studies is the disclosure of which antigens are effectively blocked by ASA in the entire cell, ultimately leading to the impairment of sperm function (e.g. motility, capacitation, acrosome reaction, and sperm-egg interaction).

Although there has been tremendous technological progress in terms of detection and analysis of biological molecules, only a few studies tried to contribute toward ASA. A recent study using the proteomic analysis of the human sperm proteins resulted in the identification of 32 antigens exclusively detected by the sera of ASApositive patients, which could be potentially responsible for immunological infertility (Nowicka-Bauer et al. 2016). Among these 32 antigens 12 (Apg-1 (HSPA4L), $60 \mathrm{kDa}$ heat shock protein, angiotensin-converting enzyme (ACE), arylsulfatase A (AS-A), dihydrolipoamide dehydrogenase (DLD), fatty acid amide hydrolase (FAAH), fumarate hydratase, proacrosin binding protein sp32 (sp32), T-complex protein 1 subunit beta isoform 1, triosephosphate isomerase 2 (TP2I), L-lactate dehydrogenase and Zn-alpha-2-glycoprotein (ZAG)) are already known for their involvement in fertilization, mainly in capacitation and sperm-oocyte interaction (Nowicka-Bauer et al. 2016).

Additionally, another study led to the identification of two human sperm proteins, which are simultaneously recognized by recombinant human zona pellucida (rhZP) glycoproteins and by ASA eluted from infertile ASA patients (Petit et al. 2013). Specifically, the glutathione S-transferase M3 (GSTM) involved in detoxification processes and crucial to sperm as it prevents sperm membrane lipid peroxidation, through ROS elimination via glutathione (Hemachand \& Shaha 2003), and the ionic channel, voltage-dependent anion-selective channel 2 (VDAC2), known to participate in energy production since it transports adenine nucleotides, $\mathrm{Ca}^{2+}$, and other metabolites at the level of the outer mitochondrial membrane (Petit et al. 2013), and already associated with male infertility (Pan et al. 2016, Xu et al. 2016).

Nonetheless, mechanistic confirmation on the actual involvement of these putative targets in mediating a possible effect on male fertility in an ASA context is still lacking.

\section{Antisperm antibodies in assisted reproduction techniques}

The screening for ASA as an integral part of semen analysis was reiterated in the last edition of $\mathrm{WHO}$ (WHO 2010), confirming the same clinically relevant threshold of $50 \%$ antibody-coated motile spermatozoa (Barbonetti et al. 2019, 2020). However, the prognostic value and the clinical significance of ASA presence alongside with the choice of the best reproductive treatment strategy, when needed, has been controversial (Barbonetti et al. 2019, 2020).

In terms of prognostic value, it was recently suggested that only a $100 \%$ ASA-positive result (MAR test) can represent the sole determinant of a couple's infertility, having a high negative prognostic value. In fact, only these $100 \%$ ASA levels were observed to be highly predictive of a poor post-coital test (PCT) outcome, a surrogate marker of infertility (Barbonetti et al. 2019, 2020), and a poor live birth rate (LBR), which is a clinical relevant endpoint, with intrauterine insemination (IUI) a relatively effective first-line treatment in these cases (Barbonetti et al. 2020). A lower degree of sperm autoimmunization (50-99\%) does not have such a strong prognostic value considering the aforementioned parameters and it cannot be considered a single determinant of infertility, representing only a contributory factor, according to these authors (Barbonetti et al. 2020). However, there are authors who advocate a $20 \%$ cut-off for ASA positivity in the IB test, based on the results of a PCT (Koriyama et al. 2013). Indeed, this $20 \%$ cut-off value for ASA positivity was already used in the past (WHO 1992). Nevertheless, the manual also referred that the result given by the IB test only has clinical significance when the threshold for antibody-coated motile spermatozoa was $50 \%$ or above. In fact, in the 1999 edition of the WHO manual, the 20\% cut-off was abandoned, and the clinical significance threshold of $50 \%$ is stressed for all the WHO-recommended tests (MAR and IB; WHO 1999, 2010).

Considering the natural reproductive process, the presence of ASA always demonstrated some negative effects and the more recent studies also corroborate this association. In fact, the study of Xu and colleagues has shown that serum ASA expression significantly correlates with low natural pregnancy rates (Xu et al. 2020). Additionally, the PCT and LBR results described in 
the studies of Barbonetti and co-workers were reported to be impaired by an elevated level of ASA bound on sperm (Barbonetti et al. 2019, 2020).

With the assisted reproduction techniques (ART), the negative effects of ASA on natural conception outcomes can be theoretically bypassed. However, according to the available literature, nicely reviewed by Zini and co-workers, the effects of ASA in the outcomes of in vitro fertilization (IVF) have been contradictory (Zini et al. 2011a) with several studies showing negative effects of ASA (Junk et al. 1986, De Almeida et al. 1989, Acosta et al. 1994, Lu et al. 2019), while others did not report any detrimental effect (Yeh et al. 1995, Culligan et al. 1998, Zini et al. 2011b). When it comes to intracytoplasmic sperm injection (ICSI) outcomes, the results are in general more concordant, with the majority of the studies showing that ASA does not influence the success of this technique (Nagy et al. 1995, Check et al. 2000, Zini et al. 2011b, Yasin et al. 2016, Lu et al. 2019). In fact, the presence of ASA does not seem to be associated with the success of reproductive outcomes after IVF or ICSI cycles (Zini et al. 2011a,b, Yasin et al. 2016, Lu et al. 2019), suggesting that both techniques are viable options for infertile couples which are facing the problem of ASA presence in semen. This may be not applicable in the context of IUI (Zini et al. 2011a), although some studies note that it may be possible to successfully overcome ASA-mediated infertility using IUI techniques (Check \& Bollendorf 1992, Lahteenmaki et al. 1995, Ombelet et al. 1997, Francavilla et al. 2009). Importantly, these authors warn that the choice of IUI when ASA are present leads to a reduction of pregnancy probability, especially when ASA levels are high (Check \& Bollendorf 1992, Francavilla et al. 1992, Check et al. 2004, van Weert et al. 2005). Also, they even reiterate that in these cases, IUI should not be the first treatment choice (Bates 1997, Check et al. 2004, Lombardo et al. 2004).

\section{Antisperm antibodies patients' treatments}

Several methodologies have been used in an attempt to overcome the negative effects of ASA on male fertility (Shibahara et al. 2005). These treatments include methods to remove ASA from the surface of the sperm cell, using repeated sperm washes with modified Hanks balanced salt solution (mHBSS), which has been demonstrated to be relatively inefficient (Haas et al. 1988). Another approach is to collect the semen samples directly into a washing buffer, for example, into the culture medium (Bronson 1987) or into a medium containing 50\% of heterologous serum or albumin fraction followed by a rapid dilution and washing (Elder et al. 1990), based on the assumption that the antibody binding on sperm can occur following ejaculation within seminal fluid, in a time-dependent manner during the liquefaction process (Bronson 1987, Elder et al. 1990). This method seems to be beneficial in some cases, maximizing the sperm recovery and minimizing the amount of ASAcoated sperm (Bronson 1987, Elder et al. 1990). Another possible treatment includes the ART options themselves, as already discussed in this review.

Regarding pharmacological approaches, corticosteroids, a class of steroid hormones, have been prescribed to treat men with ASA. Contradictory opinions regarding this topic also exist, however, with some studies confirming the clinical therapeutic relevance of corticosteroids in the treatment of men with ASA (Hendry et al. 1990, Keane et al. 1995, Omu et al. 1996), observing improvements on sperm motility (Keane et al. 1995, Omu et al. 1996), sperm count (Keane et al. 1995), hypoosmotic swelling test (Omu et al. 1996), and pregnancy rate (Hendry et al. 1990, Keane et al. 1995, Omu et al. 1996) using the corticosteroid prednisolone. Nevertheless, there were also studies that did not observe any such improvement (De Almeida et al. 1985, Haas \& Manganiello 1987, Bals-Pratsch et al. 1992). In a recent report, the administration of prednisolone was beneficial in men with ASA but without compromised sperm fusogenic capacity, assessed by the sperm penetration assay (SPA). In this case, ASA-positive prednisolone-treated men that undergo an IVF protocol had shown several improvements in IVF outcomes, namely fertilization rate, embryo cleavage rate, average embryo transfer/patient, and pregnancy rate as well as in sperm motility when compared with the non-treated infertile men with ASA (Taiyeb et al. 2017). The men who have both ASA and fusogenic problems proceeded to ICSI and the results showed no beneficial effect from the corticosteroid treatment, stressing the usefulness of the SPA test to identify the subgroup of ASA infertile men which may benefit from corticosteroid treatments (Taiyeb et al. 2017).

Finally, recently, a new approach has shown the effectiveness of the seminal plasma treatment with Staphylococcus protein A in the improvement of sperm penetration ability and in the reduction of ASA titters in immunoinfertile men (Al-Daghistani 2020). The interesting property of the Staphylococcus protein A is its high affinity for the Fc portion of $\operatorname{lgG}$ and for IgGcontaining immune complexes, leading to the selective removal of these immunoglobulins (Silverman et al. 2005). This interesting result, certainly warrant further attention, can lead to more tailored interventions in ASA patients.

\section{Conclusions: actual panorama and future perspectives}

The main purpose of this manuscript was to show how ASA-related male infertility has evolved during the last 10 years, avoiding irrelevant information, but not disregarding the many contradictory results or limitations in the technical approaches. We have reviewed all the 
important aspects, ranging from those that are best known to others that are not so well understood.

It was clear, during our analysis, that many aspects are not straightforward when we talk about ASAmediated male infertility. Despite the design flaws in some studies, as well as a general lack of consensus regarding the thresholds to be used, it is also clear that the mechanisms by which ASA occur, to their effects on the sperm cells and subsequent fertilization, are still poorly understood. This is, in our opinion, one of the greatest handicaps in the field, and we believe that this is where future research should be firstly focused on producing reliable data on large cohorts.

With a concerted effort, we believe that it will bepossible to clarify the real prevalence of this type of infertility, that has been halted by the variety of methodologies and cutoff values used so far, and importantly the exact impact of ASA on sperm and male reproductive function, allowing to define better strategies of intervention, if justified. Hopefully, the upcoming 6th edition of the manual for examination and processing of the human semen, which was already distributed for preview and comments, will have indications in this regard.

Finally, we could not finish this review without saying a word on the actual world pandemic situation due to SARS-CoV-2 infection and of the possible role of COVID19 disease in male fertility, a subject that has been actively studied in a series of recent papers. It would also be logical to hypothesize the ASA development in patients with COVID-19 and the study on how this will impact fertility. The reasons for this were elegantly summarized in a recent work (Haghpanah et al. 2021) and are related with the angiotensin-converting enzyme 2 (ACE2) receptors, which are the virus entrance door in the host cells (Hoffmann et al. 2020), and which are present on spermatogonia, Sertoli cells, and Leydig cells (Haghpanah et al. 2021). With all these cell types expressing ACE2 receptors, the reproductive system may be a target of infection and taken into account the possible subsequent inflammatory process, certainly, ASA production may be a possibility and should be considered in upcoming studies (Haghpanah et al. 2021).

\section{Supplementary materials}

This is linked to the online version of the paper at https://do i.org/10.1530/REP-21-0123.

\section{Declaration of interest}

The authors declare that there is no conflict of interest that could be perceived as prejudicing the impartiality of this review.

\section{Funding}

This work was supported by Fundação para a Ciência e Tecnologia (FCT) Portugal, for PhD scholarship attributed to
AFS (SFRH/BD/129429/2017). This work was also financed by the European Regional Development Fund (ERDF), through the COMPETE 2020 - Operational Programme for Competitiveness and Internationalisation and Portuguese national funds via FCT - Fundação para a Ciência e a Tecnologia, under the projects POCI-01-0145-FEDER-028599 (INFERT2EXPLAIN), UIDB/04539/2020 and CENTRO-01-0145-FEDER-000012-He althyAging2020.

\section{Author contribution statement}

A F S and S A conceived and designed the study. A F S performed literature search and wrote the draft of the manuscript. A F S, S A, and J R S contributed to the critical discussion of the manuscript. S A and J R S revised the final draft of the manuscript. All authors approved the final version of the manuscript.

\section{Acknowledgements}

The authors would like to thank to all the members of the Biology of Reproduction and Stem Cell research group, at the Center for Neuroscience and Cell Biology (CNC) of the University of Coimbra. The authors would also like to thank J Saints for proof reading of the final manuscript.

\section{References}

Acosta AA, Van der Merwe JP, Doncel G, Kruger TF, Sayilgan A, Franken DR \& Kolm P 1994 Fertilization efficiency of morphologically abnormal spermatozoa in assisted reproduction is further impaired by antisperm antibodies on the male partner's sperm. Fertility and Sterility 62 826-833. (https://doi.org/10.1016/s0015-0282(16)57012-5)

Adeghe JHA 1993 Male subfertility due to sperm antibodies: a clinical overview. Obstetrical and Gynecological Survey 48 1-8. (https://doi. org/10.1097/00006254-199301000-00001)

Agarwal A, Deepinder F, Cocuzza M, Agarwal R, Short RA, Sabanegh E \& Marmar JL 2007 Efficacy of varicocelectomy in improving semen parameters: new meta-analytical approach. Urology 70 532-538. (https://doi.org/10.1016/j.urology.2007.04.011)

Al-Adl AM, El-Karamany T, Issa H \& Zaazaa M 2014 The influence of antisperm antibodies, intratesticular haemodynamics and the surgical approach to varicocelectomy on seminal variables. Arab Journal of Urology 12 309-317. (https://doi.org/10.1016/j.aju.2014.07.001)

Al-Daghistani HI 2020 Staphylococcus aureus protein A as a means of assessing sperm penetrability in cervical mucus in vitro. Clinical and Experimental Reproductive Medicine 47 186-193. (https://doi. org/10.5653/cerm.2020.03279)

Ashman JB, Hall ES, Eveleth J \& Boekelheide K 1992 Tau, the neuronal heatstable microtubule-associated protein, is also present in the cross-linked microtubule network of the testicular spermatid manchette. Biology of Reproduction 46 120-129. (https://doi.org/10.1095/biolreprod46.1.120)

Azizi G, Namaki S, Mirshafiey A \& Hamid KM 2015 HLA antigens and anti-sperm antibody production in Iranian vasectomized men. Journal of Biomedical Research 29 87-90. (https://doi.org/10.7555/ JBR.29.20140113)

Bals-Pratsch M, Dören M, Karbowski B, Schneider HPG \& Nieschlag E 1992 Cyclic corticosteroid immunosuppression is unsuccessful in the treatment of sperm antibody-related male infertility: a controlled study. Human Reproduction 7 99-104. (https://doi.org/10.1093/oxfordjournals. humrep.a137568)

Barbonetti A, Castellini C, D'Andrea S, Cordeschi G, Santucci R, Francavilla S \& Francavilla F 2019 Prevalence of anti-sperm antibodies and relationship of degree of sperm auto-immunization to semen parameters and post-coital test outcome: a retrospective analysis of 
over 10000 men. Human Reproduction 34 834-841. (https://doi. org/10.1093/humrep/dez030)

Barbonetti A, Castellini C, D'Andrea S, Minaldi E, Totaro M, Francavilla S \& Francavilla F 2020 Relationship between natural and intrauterine insemination-assisted live births and the degree of sperm autoimmunisation. Human Reproduction 35 1288-1295. (https://doi. org/10.1093/humrep/deaa070)

Bates CA 1997 Antisperm antibodies and male subfertility. British Journal of Urology $\mathbf{8 0}$ 691-697. (https://doi.org/10.1046/j.1464410x.1997.00379.x)

Bohring C \& Krause W 2003 Immune infertility: towards a better understanding of sperm (auto)-immunity: the value of proteomic analysis. Human Reproduction 18 915-924. (https://doi.org/10.1093/ humrep/deg207)

Bollendorf A \& Check JH 2016 Correlation of ImmunoBead $(\mathbb{3}$ and ImmunoSphere ${ }^{\mathrm{TM}}$ immunoglobulin G (IGG) tests on detecting antisperm antibody (ASA) on sperm. Clinical and Experimental Obstetrics and Gynecology 43 175-177.

Bonyadi MR, Madaen SK \& Saghafi M 2013 Effects of varicocelectomy on anti-sperm antibody in patients with varicocele. Journal of Reproduction and Infertility 14 73-78.

Bozhedomov VA, Lipatova NA, Rokhlikov IM, Alexeev RA, Ushakova IV \& Sukhikh GT 2014a Male fertility and varicocoele: role of immune factors. Andrology 2 51-58. (https://doi.org/10.1111/j.20472927.2013.00160.x)

Bozhedomov VA, Lipatova NA, Alexeev RA, Alexandrova LM, Nikolaeva MA \& Sukhikh GT $2014 b$ The role of the antisperm antibodies in male infertility assessment after microsurgical varicocelectomy. Andrology 2 847-855. (https://doi.org/10.1111/j.2047-2927.2014.00254.x)

Bozhedomov VA, Nikolaeva MA, Ushakova IV, Lipatova NA, Bozhedomova GE \& Sukhikh GT 2015 Functional deficit of sperm and fertility impairment in men with antisperm antibodies. Journal of Reproductive Immunology 112 95-101. (https://doi.org/10.1016/j. jri.2015.08.002)

Brincat D, Catania S, Wismayer PS \& Calleja-Agius J 2015 Male factors in ART outcome prediction. Gynecological Endocrinology 31 169-175. (https://doi.org/10.3109/09513590.2014.984678)

Bronson R 1987 Immunity in sperm and in vitro fertilization. Journal of In Vitro Fertilization and Embryo Transfer 4 195-197. (https://doi. org/10.1007/BF01533756)

Brunner-Agten S, Pavlovic R, Müller L, Horn MP, Huber AR, Stadler BM \& Vogel M 2013 Increased level of antibodies cross-reacting with ves $\vee 5$ and CRISP-2 in MAR-positive patients. International Archives of Allergy and Immunology 160 47-55. (https://doi.org/10.1159/000338946)

Busso D, Cohen DJ, Hayashi M, Kasahara M \& Cuasnicú PS 2005 Human testicular protein TPX1/CRISP-2: localization in spermatozoa, fate after capacitation and relevance for gamete interaction. Molecular Human Reproduction 11 299-305. (https://doi.org/10.1093/molehr/gah156)

Chaffee JK \& Schachner M 1978a NS-6 (nervous system antigen-6): a new cell surface antigen of brain, kidney, and spermatozoa. Developmental Biology 62 173-184. (https://doi.org/10.1016/0012-1606(78)90099-4)

Chaffee JK \& Schachner M 1978b NS-7 (nervous system antigen-7): a cell surface antigen of mature brain, kidney, and spermatozoa shared by embryonal tissues and transformed cells. Developmental Biology 62 185-192. (https://doi.org/10.1016/0012-1606(78)90100-8)

Chamley LW \& Clarke GN 2007 Antisperm antibodies and conception. Seminars in Immunopathology 29 169-184. (https://doi.org/10.1007/ s00281-007-0075-2)

Check JH \& Bollendorf A 1992 Effect of antisperm antibodies on postcoital results and effect of intrauterine insemination on pregnancy outcome. Archives of Andrology 28 25-31. (https://doi. org/10.3109/01485019208987676)

Check ML, Check JH, Katsoff D \& Summers-Chase D 2000 ICSI as an effective therapy for male factor with antisperm antibodies. Archives of Andrology 45 125-130. (https://doi.org/10.1080/01485010050193887)

Check JH, Hourani W, Check ML, Graziano V \& Levin E 2004 Effect of treating antibody-coated sperm with chymotrypsin on pregnancy rates following IUI as compared to outcome of IVF/ICSI. Archives of Andrology 50 93-95. (https://doi.org/10.1080/aan.50.2.93.95)

Chung E \& Brock GB 2011 Cryptorchidism and its impact on male fertility: a state of art review of current literature. Canadian Urological Association Journal 5 210-214. (https://doi.org/10.5489/cuaj.10106)
Collins JA, Burrows EA, Yeo J \& Younglai EV 1993 Frequency and predictive value of antisperm antibodies among infertile couples. Human Reproduction 8 592-598. (https://doi.org/10.1093/oxfordjournals. humrep.a138102)

Coussens LM \& Werb Z 2002 Inflammation and cancer. Nature 420 860-867. (https://doi.org/10.1038/nature01322)

Cui D, Han G, Shang Y, Liu C, Xia L, Li L \& Yi S 2015 Antisperm antibodies in infertile men and their effect on semen parameters: a systematic review and meta-analysis. Clinica Chimica Acta: International Journal of Clinical Chemistry 444 29-36. (https://doi.org/10.1016/j.cca.2015.01.033)

Culligan PJ, Crane MM, Boone WR, Allen TC, Price TM \& Blauer KL 1998 Validity and cost-effectiveness of antisperm antibody testing before in vitro fertilization. Fertility and Sterility 69 894-898. (https://doi. org/10.1016/s0015-0282(98)00034-x)

Cuppett VA, Sikka SC \& Naz RK 2017 Presence of PSA antibodies in seminal plasma of infertile men. Frontiers in Bioscience 9 258-265. (https://doi.org/10.2741/e800)

De Almeida M, Feneux D, Rigaud C \& Jouannet P 1985 Steroid therapy for male infertility associated with antisperm antibodies: results of a small randomized clinical trial. International Journal of Andrology 8 111-117. (https://doi.org/10.1111/j.1365-2605.1985.tb00824.x)

De Almeida M, Gazagne I, Jeulin C, Herry M, Belaisch-Allart J, Frydman R, Jouannet P \& Testart J 1989 In-vitro processing of sperm with autoantibodies and in-vitro fertilization results. Human Reproduction $\mathbf{4}$ 49-53. (https://doi.org/10.1093/oxfordjournals.humrep.a136844)

Diemer T, Huwe P, Ludwig M, Hauck EW \& Weidner W 2003 Urogenital infection and sperm motility. Andrologia 35 283-287. (https://doi. org/10.1111/j.1439-0272.2003.tb00858.x)

Dohle GR, Diemer T, Giwercman A, Jungwirth A, Kopa Z \& Krausz C 2010 Guidelines on Male Infertility, pp. 1-64. European Association of Urology.

Eggert-Kruse W, Neuer A, Clussmann C, Boit R, Geissler W, Rohr G \& Strowitzki T 2002 Seminal antibodies to human $60 \mathrm{kd}$ heat shock protein (HSP 60) in male partners of subfertile couples. Human Reproduction 17 726-735. (https://doi.org/10.1093/humrep/17.3.726)

Eggert-Kruse W, Batschulat K, Demirakca T \& Strowitzki T 2015 Male immunity to the chlamydial $60 \mathrm{kDa}$ heat shock protein (HSP 60): associated with semen quality? Andrologia 47 66-76. (https://doi. org/10.1111/and.12224)

Elder KT, Wick KL \& Edwards RG 1990 Seminal plasma anti-sperm antibodies and IVF: the effect of semen sample collection into 50\% serum. Human Reproduction 5 179-184. (https://doi.org/10.1093/ oxfordjournals.humrep.a137065)

Evenson DP, Jost LK, Marshall D, Zinaman MJ, Clegg E, Purvis K, De Angelis P \& Ciaussen OP 1999 Utility of the sperm chromatin structure assay as a diagnostic and prognostic tool in the human fertility clinic. Human Reproduction 14 1039-1049. (https://doi.org/10.1093/ humrep/14.4.1039)

Foresta C, Noventa M, De Toni L, Gizzo S \& Garolla A 2015 HPV-DNA sperm infection and infertility: from a systematic literature review to a possible clinical management proposal. Andrology 3 163-173. (https:// doi.org/10.1111/andr.284)

Francavilla F \& Barbonetti A 2009 Male autoimmune infertility. In Immune Infertility, pp. 145-153. Eds W Krause \& R Naz. Berlin, Heidelberg: Springer.

Francavilla F, Romano R, Santucci R, Marrone V \& Corrao G 1992 Failure of intrauterine insemination in male immunological infertility in cases in which all spermatozoa are antibody-coated. Fertility and Sterility $\mathbf{5 8}$ 587-592. (https://doi.org/10.1016/S0015-0282(16)55268-6)

Francavilla F, Sciarretta F, Sorgentone S, Necozione S, Santucci R, Barbonetti A \& Francavilla S 2009 Intrauterine insemination with or without mild ovarian stimulation in couples with male subfertility due to oligo/astheno- and/or teratozoospermia or antisperm antibodies: a prospective cross-over trial. Fertility and Sterility 92 1009-1011. (https:// doi.org/10.1016/j.fertnstert.2009.01.112)

Gandini L, Lenzi A, Culasso F, Lombardo F, Paoli D \& Dondero F 1995 Study of antisperm antibodies bound to the sperm cell surface and their relationship to circulating ASA. American Journal of Reproductive Immunology 34 375-380. (https://doi.org/10.1111/j.1600-0897.1995. tb00967.x)

Garolla A, Pizzol D, Bertoldo A, De Toni L, Barzon L \& Foresta C 2013 Association, prevalence, and clearance of human papillomavirus 
and antisperm antibodies in infected semen samples from infertile patients. Fertility and Sterility 99 125-131. (https://doi.org/10.1016/j. fertnstert.2012.09.006)

Garolla A, De Toni L, Bottacin A, Valente U, De Rocco Ponce M, Di Nisio A \& Foresta C 2018 Human papillomavirus prophylactic vaccination improves reproductive outcome in infertile patients with HPV semen infection: a retrospective study. Scientific Reports 8 912. (https://doi. org/10.1038/s41598-018-19369-z)

Gatimel N, Moreau J, Isus F, Moinard N, Parinaud J \& Leandri RD 2018 Anti-sperm antibodies detection by a modified MAR test: towards a better definition of its indications. Reproductive Biomedicine Online 37 717-723. (https://doi.org/10.1016/j.rbmo.2018.09.011)

Gilbert BR, Witkin SS \& Goldstein M 1989 Correlation of sperm-bound immunoglobulins with impaired semen analysis in infertile men with varicoceles. Fertility and Sterility 52 469-473. (https://doi.org/10.1016/ s0015-0282(16)60921-4)

Golomb J, Vardinon N, Homonnai ZT, Braf Z \& Yust I 1986 Demonstration of antispermatozoal antibodies in varicocele-related infertility with an enzyme-linked immunosorbent assay (ELISA). Fertility and Sterility $\mathbf{4 5}$ 397-402. (https://doi.org/10.1016/s0015-0282(16)49224-1)

Gubin DA, Dmochowski R \& Kutteh WH 1998 Multivariant analysis of men from infertile couples with and without antisperm antibodies. American Journal of Reproductive Immunology 39 157-160. (https://doi. org/10.1111/j.1600-0897.1998.tb00348.x)

Gupta S, Krishna A, Jain M, Goyal A, Kumar A, Chaturvedi P, Sagar R, Ramachandran R, Prakash O, Kumar S et al. 2021 A three-arm randomized study to compare sexual functions and fertility indices following open mesh hernioplasty $(\mathrm{OMH})$, laparoscopic totally extra peritoneal (TEP) and transabdominal preperitoneal (TAPP) repair of groin hernia. Surgical Endoscopy 35 3077-3084. (https://doi.org/10.1007/ s00464-020-07697-z)

Haas GG \& Cunningham ME 1984 Identification of antibody-laden sperm by cytofluorometry. Fertility and Sterility 42 606-613. (https://doi. org/10.1016/s0015-0282(16)48146-x)

Haas Jr GG \& Manganiello P 1987 A double-blind, placebo-controlled study of the use of methylprednisolone in infertile men with spermassociated immunoglobulins. Fertility and Sterility 47 295-301. (https:// doi.org/10.1016/S0015-0282(16)50009-0)

Haas Jr GG, D'Cruz OJ \& Denum BM 1988 Effect of repeated washing on sperm-bound immunoglobulin G. Journal of Andrology 9 190-196. (https://doi.org/10.1002/j.1939-4640.1988.tb01033.x)

Haghpanah A, Masjedi F, Alborzi S, Hosseinpour A, Dehghani A, Malekmakan L \& Roozbeh J 2021 Potential mechanisms of SARS-CoV-2 action on male gonadal function and fertility: current status and future prospects. Andrologia 53 e13883. (https://doi.org/10.1111/and.13883)

Han C, Kim NH, Kwon DY, Seo WK \& Park MH 2010 Lack of association between antisperm antibodies and language dysfunction in Alzheimer's disease. Archives of Gerontology and Geriatrics 50 338-340. (https:// doi.org/10.1016/j.archger.2009.05.014)

Hedger MP 2011 Immunophysiology and pathology of inflammation in the testis and epididymis. Journal of Andrology 32 625-640. (https://doi. org/10.2164/jandrol.111.012989)

Heidenreich A, Bonfig R, Wilbert DM, Strohmaier WL \& Engelmann UH 1994 Risk factors for antisperm antibodies in infertile men. American Journal of Reproductive Immunology 31 69-76. (https://doi. org/10.1111/j.1600-0897.1994.tb00849.x)

Hellstrom WJ, Samuels SJ, Waits AB \& Oversteet JW 1989 A comparison of the usefulness of SpermMar and immunobead tests for the detection of antisperm antibodies. Fertility and Sterility 52 1027-1031. (https://doi. org/10.1016/s0015-0282(16)53170-7)

Helmerhorst FM, Finken MJ \& Erwich JJ 1999 Antisperm antibodies: detection assays for antisperm antibodies: what do they test? Human Reproduction 14 1669-1671. (https://doi.org/10.1093/ humrep/14.7.1669)

Hemachand T \& Shaha C 2003 Functional role of sperm surface glutathione S-transferases and extracellular glutathione in the haploid spermatozoa under oxidative stress. FEBS Letters 538 14-18. (https://doi.org/10.1016/ s0014-5793(03)00103-0)

Hendry WF, Hughes L, Scammell G, Pryor JP \& Hargreave TB 1990 Comparison of prednisolone and placebo in subfertile men with antibodies to spermatozoa. Lancet 335 85-88. (https://doi. org/10.1016/0140-6736(90)90548-j)
Hinz S, Rais-Bahrami S, Kempkensteffen C, Weiske WH, Miller K \& Magheli A 2010 Effect of obesity on sex hormone levels, antisperm antibodies, and fertility after vasectomy reversal. Urology 76 851-856. (https://doi.org/10.1016/j.urology.2010.01.055)

Hoffmann M, Kleine-Weber $H$, Schroeder S, Krüger $N$, Herrler T, Erichsen S, Schiergens TS, Herrler G, Wu NH, Nitsche A et al. 2020 SARS-CoV-2 cell entry depends on ACE2 and TMPRSS2 and is blocked by a clinically proven protease inhibitor. Cell 181 271-280. (https://doi. org/10.1016/j.cell.2020.02.052)

Hoover P \& Naz RK 2012 Do men with prostate abnormalities (prostatitis/benign prostatic hyperplasia/prostate cancer) develop immunity to spermatozoa or seminal plasma? International Journal of Andrology 35 608-615. (https://doi.org/10.1111/j.13652605.2011.01246.x)

Hussein TM, Elneily D, Eid AA \& Abou-ElKhier H 2017 Assessment of antisperm antibodies in a sample of Egyptian patients with hepatitis C virus infection. Andrologia 49 1-5. (https://doi.org/10.1111/and.12664)

Imamoğlu M, Bülbül SS, Kaklikkaya N \& Sarihan H 2012 Oxidative, inflammatory and immunologic status in children with undescended testes. Pediatrics International 54 816-819. (https://doi.org/10.1111/ j.1442-200X.2012.03695.x)

Isitmangil G, Yildirim S, Orhan I, Kadioglu A \& Akinci M 1999 A comparison of the sperm mixed-agglutination reaction test with the peroxidase-labelled protein A test for detecting antisperm antibodies in infertile men with varicocele. BJU International 84 835-838. (https://doi. org/10.1046/j.1464-410x.1999.00283.x)

James ES, Harney S, Wordsworth BP, Cookson WOCM, Davis SJ \& Moffatt MF 2005 PDCD1: a tissue-specific susceptibility locus for inherited inflammatory disorders. Genes and Immunity 6 430-437. (https://doi.org/10.1038/sj.gene.6364223)

Jarow JP 2002 Serum sperm antibodies are not elevated after mumps orchitis. Journal of Urology 168 860-861. (https://doi.org/10.1016/ S0022-5347(05)64767-2)

Jensen CFS, Khan O, Nagras ZG, Sønksen J, Fode M, Østergren PB, Shah T, Ohl DA \& CopMich Collaborative 2018 Male infertility problems of patients with strict sperm morphology between $5-14 \%$ may be missed with the current WHO guidelines. Scandinavian Journal of Urology 52 427-431. (https://doi.org/10.1080/21681805.2018.1548503)

Jiang H \& Zhu WJ 2013a Cryptorchidism is not a risk factor for antisperm antibody production in post-orchidopexy males with infertility. Urologia Internationalis 90 470-474. (https://doi.org/10.1159/000348824)

Jiang H \& Zhu W-J 2013b Testicular microlithiasis is not a risk factor for the production of antisperm antibody in infertile males. Andrologia 45 305-309. (https://doi.org/10.1111/and.12002)

Jiang Y, Cui D, Du Y, Lu J, Yang L, Li J, Zhang J \& Bai X 2016 Association of anti-sperm antibodies with chronic prostatitis: a systematic review and meta-analysis. Journal of Reproductive Immunology 118 85-91. (https:// doi.org/10.1016/j.jri.2016.09.004)

Johnson RE, Newhall WJ, Papp JR, Knapp JS, Black CM, Gift TL, Steece R, Markowitz LE, Devine OJ, Walsh CM et al. 2002 Screening tests to detect Chlamydia trachomatis and Neisseria gonorrhoeae infections-2002. Morbidity and Mortality Weekly Report: Recommendations and Reports 51 1-38; quiz CE1-4.

Jones DB, Coulson AFW \& Duff GW 1993 Sequence homologies between hsp60 and autoantigens. Immunology Today 14 115-118. (https://doi. org/10.1016/0167-5699(93)90210-C)

Jungwirth A, Diemer T, Kopa Z, Krausz C, Minhas S \& Tournaye 2019 European Association of Urology Guidelines on Male Infertility, pp. 1-48. European Association of Urology.

Junk SM, Matson PL, Yovich JM, Bootsma B \& Yovich JL 1986 The fertilization of human oocytes by spermatozoa from men with antispermatozoal antibodies in semen. Journal of In Vitro Fertilization and Embryo Transfer 3 350-352. (https://doi.org/10.1007/BF01133246)

Kalaydjiev S, Dimitrova D, Tsvetkova P \& Tsvetkov D 2001 Serum sperm antibodies unrelated to mumps orchitis. Andrologia 33 69-70. (https:// doi.org/10.1046/j.1439-0272.2001.00371.x)

Kalaydjiev S, Dimitrova D, Nenova M, Peneva S, Dikov I \& Nakov L 2002 Serum sperm antibodies are not elevated after mumps orchitis. Fertility and Sterility 77 76-82. (https://doi.org/10.1016/s0015-0282(01)029260)

Keane D, Jenkins DM, Higgins T, O'Neill M, Mulcahy MF \& Ferriss JB 1995 The effect of intermittent steroid therapy on anti-sperm antibody levels. 
European Journal of Obstetrics, Gynecology, and Reproductive Biology 63 75-79. (https://doi.org/10.1016/0301-2115(95)02217-u)

Knudson G, Ross L, Stuhldreher D, Houlihan D, Bruns E \& Prins G 1994 Prevalence of sperm bound antibodies in infertile men with varicocele: the effect of varicocele ligation on antibody levels and semen response. Journal of Urology 151 1260-1262. (https://doi.org/10.1016/s00225347(17)35226-6)

Komori K, Tsujimura A, Miura H, Shin M, Takada T, Honda M, Matsumiya K \& Fujioka H 2004 Serial follow-up study of serum testosterone and antisperm antibodies in patients with non-obstructive azoospermia after conventional or microdissection testicular sperm extraction. International Journal of Andrology 27 32-36. (https://doi.org/10.1046/ j.0105-6263.2003.00443.x)

Koriyama J, Shibahara H, Ikeda T, Hirano Y, Suzuki T \& Suzuki M 2013 Toward standardization of the cut-off value for the direct immunobead test using the postcoital test in immunologically infertile males. Reproductive Medicine and Biology 12 21-25. (https://doi.org/10.1007/ s12522-012-0135-8)

Kramer G, Mitteregger D \& Marberger M 2007 Is benign prostatic hyperplasia (BPH) an immune inflammatory disease? European Urology 51 1202-1216. (https://doi.org/10.1016/j.eururo.2006.12.011)

Krause WKH 2009 Sperm functions influenced by immune reactions. In Immune Infertility, pp. 49-65. Eds W Krause \& R Naz. Berlin, Heidelberg: Springer.

Krause WKH \& Naz RK 2009 Immune Infertility, pp. 1-126. Berlin Heidelberg, Germany: Springer-Verlag.

Kremer J \& Jager S 1980 Characteristics of anti-spermatozoal antibodies responsible for the shaking phenomenon with special regard to immunoglobulin class and antigen-reactive sites. International Journal of Andrology 3 143-152. (https://doi.org/10.1111/j.1365-2605.1980. tb00103.x)

Krnić D, Družijanić N, Štula I, Čapkun V \& Krnić D 2016 Incarcerated inguinal hernia mesh repair: effect on testicular blood flow and sperm autoimmunity. Medical Science Monitor 22 1524-1533. (https://doi. org/10.12659/msm.898727)

Kroner A, Mehling M, Hemmer B, Rieckmann P, Toyka KV, Mäurer M \& Wiendl H 2005 A PD-1 polymorphism is associated with disease progression in multiple sclerosis. Annals of Neurology 58 50-57. (https:// doi.org/10.1002/ana.20514)

Kurpisz M, Nakonechnyy A, Niepieklo-Miniewska W, Havrylyuk A, Kamieniczna M, Nowakowska B, Chopyak V \& Kusnierczyk P 2011 Weak association of anti-sperm antibodies and strong association of familial cryptorchidism/infertility with HLA-DRB1 polymorphisms in prepubertal Ukrainian boys. Reproductive Biology and Endocrinology 9 129. (https://doi.org/10.1186/1477-7827-9-129)

Lahteenmaki A, Veilahti J \& Hovatta O 1995 Intra-uterine insemination versus cyclic, low-dose prednisolone in couples with male antisperm antibodies. Human Reproduction 10 142-147. (https://doi.org/10.1093/ humrep/10.1.142)

Law HY, Bodmer WF, Mathews JD \& Skegg DCG 1979 The immune response to vasectomy and its relation to the HLA system. Tissue Antigens 14 115-139. (https://doi.org/10.1111/j.1399-0039.1979. tb00830.x)

Lee SH, Lee YA, Woo DH, Song R, Park EK, Ryu MH, Kim YH, Kim KS, Hong SJ, Yoo MC et al. 2006 Association of the programmed cell death 1 (PDCD1) gene polymorphism with ankylosing spondylitis in the Korean population. Arthritis Research and Therapy 8 R163. (https://doi. org/10.1186/ar2071)

Lee R, Goldstein M, Ullery BW, Ehrlich J, Soares M, Razzano RA, Herman MP, Callahan MA, Li PS, Schlegel PN et al. 2009 Value of serum antisperm antibodies in diagnosing obstructive azoospermia. Journal of Urology 181 264-269. (https://doi.org/10.1016/j.juro.2008.09.004)

Lin SC, Yen JH, Tsai JJ, Tsai WC, Ou TT, Liu HW \& Chen CJ 2004 Association of a programmed death 1 gene polymorphism with the development of rheumatoid arthritis, but not systemic lupus erythematosus. Arthritis and Rheumatism 50 770-775. (https://doi. org/10.1002/art.20040)

Liu MM, Liu L, Chen L, Yin XJ, Liu H, Zhang YH, Li PL, Wang S, Li XX \& Yu CH 2017 Sleep deprivation and late bedtime impair sperm health through increasing antisperm antibody production: a prospective study of 981 healthy men. Medical Science Monitor 23 1842-1848. (https:// doi.org/10.12659/msm.900101)
Lombardo F, Gandini L, Dondero F \& Lenzi A 2001 Antisperm immunity in natural and assisted reproduction. Human Reproduction Update 7 450-456. (https://doi.org/10.1093/humupd/7.5.450)

Lombardo F, Gandini L, Lenzi A \& Dondero F 2004 Antisperm immunity in assisted reproduction. Journal of Reproductive Immunology 62 101-109. (https://doi.org/10.1016/j.jri.2003.08.005)

Lomboy JR \& Coward RM 2016 The varicocele: clinical presentation, evaluation, and surgical management. Seminars in Interventional Radiology 33 163-169. (https://doi.org/10.1055/s-0036-1586143)

Lotti F, Baldi E, Corona G, Lombardo F, Maseroli E, Degl'Innocenti S, Bartoli L \& Maggi M 2018 Epididymal more than testicular abnormalities are associated with the occurrence of antisperm antibodies as evaluated by the MAR test. Human Reproduction 33 1417-1429. (https://doi. org/10.1093/humrep/dey235)

Lu JC, Zhang HY, Hu YA, Huang YF \& Lü NQ 2010 A survey on the status of semen analysis in 118 laboratories in China. Asian Journal of Andrology 12 104-110. (https://doi.org/10.1038/aja.2008.41)

Lu SM, Li X, Wang SL, Yang XL, Xu YZ, Huang LL, Liu JL, Cai FF \& Chen Z] 2019 Success rates of in vitro fertilization versus intracytoplasmic sperm injection in men with serum anti-sperm antibodies: a consecutive cohort study. Asian Journal of Andrology 21 473-477. (https://doi.org/10.4103/ aja.aja_124_18)

Luttmer R, Dijkstra MG, Snijders PJF, Hompes PGA, Pronk DTM, Hubeek I, Berkhof J, Heideman DAM \& Meijer CJLM 2016 Presence of human papillomavirus in semen in relation to semen quality. Human Reproduction 31 280-286. (https://doi.org/10.1093/humrep/dev317)

MacMillan RA \& Baker HW 1987 Comparison of latex and polyacrylamide beads for detecting sperm antibodies. Clinical Reproduction and Fertility 5 203-209.

Marconi M \& Weidner W 2017 Site and risk factors of antisperm antibodies production in the male population. In Immune Infertility, pp. 133-147. Eds W Krause \& R Naz. Switzerland: Springer International Publishing.

Marconi M, Nowotny A, Pantke P, Diemer T \& Weidner W 2008 Antisperm antibodies detected by mixed agglutination reaction and immunobead test are not associated with chronic inflammation and infection of the seminal tract. Andrologia 40 227-234. (https://doi.org/10.1111/j.14390272.2008.00848.x)

Marconi M, Pilatz A, Wagenlehner F, Diemer T \& Weidner W 2009 Are antisperm antibodies really associated with proven chronic inflammatory and infectious diseases of the male reproductive tract? European Urology $\mathbf{5 6}$ 708-715. (https://doi.org/10.1016/j. eururo.2008.08.001)

Martínez-Prado E \& Camejo Bermúdez MI 2010 Expression of IL-6, IL8, TNF- $\alpha$, IL-10, HSP-60, anti-HSP-60 antibodies, and anti-sperm antibodies. American Journal of Reproductive Immunology 63 233-243. (https://doi.org/10.1111/j.1600-0897.2009.00786.x)

Mazumdar S \& Levine AS 1998 Antisperm antibodies: etiology, pathogenesis, diagnosis, and treatment. Fertility and Sterility $\mathbf{7 0}$ 799-810. (https://doi.org/10.1016/s0015-0282(98)00302-1)

Meinertz H \& Bronson R 1988 Detection of antisperm antibodies on the surface of motile spermatozoa: comparison of the immunobead binding technique (IBT) and the mixed antiglobulin reaction (MAR). American Journal of Reproductive Immunology and Microbiology 18 120-123. (https://doi.org/10.1111/j.1600-0897.1988.tb00247.x)

Morrison RP, Manning DS \& Caldwell HD 1992 Immunology of Chlamydia trachomatis infection: immunoprotective and immunopathogenetic responses. In Sexually Transmitted Diseases, pp. 57-84. Ed TC Quinn. New York, NY: Raven Press.

Müller L, Vogel M, Stadler M, Truffer R, Rohner E \& Stadler BM 2008 Sensitization to wasp venom does not induce autoantibodies leading to infertility. Molecular Immunology 45 3775-3785. (https://doi. org/10.1016/j.molimm.2008.05.024)

Naaby-Hansen S \& Herr JC 2010 Heat shock proteins on the human sperm surface. Journal of Reproductive Immunology 84 32-40. (https://doi. org/10.1016/j.jri.2009.09.006)

Nagy ZP, Verheyen G, Liu J, Joris H, Janssenswillen C, Wisanto A, Devroey P \& Van Steirteghem AC 1995 Results of 55 intracytoplasmic sperm injection cycles in the treatment of male-immunological infertility. Human Reproduction 10 1775-1780. (https://doi.org/10.1093/ oxfordjournals.humrep.a136172)

Naz RK 1997 Prostate: Basic and Clinical Aspects, pp. 1-377. Boca Raton, Florida: CRC Press Press. 
Naz RK \& Butler TS 2013 Antibodies to prostate-specific antigen in immunoinfertile women and men. Journal of Reproductive Immunology 97 217-222. (https://doi.org/10.1016/j.jri.2012.11.005)

Nielsen C, Hansen D, Husby S, Jacobsen BB \& Lillevang ST 2003 Association of a putative regulatory polymorphism in the PD-1 gene with susceptibility to type 1 diabetes. Tissue Antigens 62 492-497. (https://doi.org/10.1046/j.1399-0039.2003.00136.x)

Niepiekło-Miniewska W, Kuśnierczyk P, Havrylyuk A, Kamieniczna M, Nakonechnyy A, Chopyak V \& Kurpisz M 2015 Killer cell immunoglobulinlike receptor gene association with cryptorchidism. Reproductive Biology 15 217-222. (https://doi.org/10.1016/j.repbio.2015.08.001)

Nishimura H, Nose M, Hiai H, Minato N \& Honjo T 1999 Development of lupus-like autoimmune diseases by disruption of the PD-1 gene encoding an ITIM motif-carrying immunoreceptor. Immunity 11 141-151. (https://doi.org/10.1016/s1074-7613(00)80089-8)

Nowicka-Bauer K, Kamieniczna M, Cibulka J, Ulcova-Gallova Z \& Kurpisz M 2016 Proteomic identification of sperm antigens using serum samples from individuals with and without antisperm antibodies. Andrologia 48 693-701. (https://doi.org/10.1111/and.12502)

Nukumizu LA, Saad CG, Ostensen M, Almeida BP, Cocuzza $M$, Gonçalves C, Saito O, Bonfá E \& Silva CA 2012 Gonadal function in male patients with ankylosing spondylitis. Scandinavian Journal of Rheumatology 41 476-481. (https://doi.org/10.3109/03009742.2012.6 88218)

Ochsendorf FR 2008 Sexually transmitted infections: impact on male fertility. Andrologia 40 72-75. (https://doi.org/10.1111/j.14390272.2007.00825.x)

Ombelet W, Vandeput H, Janssen M, Cox A, Vossen C, Pollet H, Steeno O \& Bosmans E 1997 Treatment of male infertility due to sperm surface antibodies: IUI or IVF? Human Reproduction 12 1165-1170. (https:// doi.org/10.1093/humrep/12.6.1165)

Omu AE, Al-Qattan F \& Hamada BA 1996 Effect of low dose continuous corticosteroid therapy in men with antisperm antibodies on spermatozoal quality and conception rate. European Journal of Obstetrics, Gynecology, and Reproductive Biology 69 129-134. (https://doi.org/10.1016/03012115(95)02539-1)

Oshinsky GS, Rodriguez MV \& Mellinger BC 1993 Varicocele-related infertility is not associated with increased sperm-bound antibody. Journal of Urology 150 871-873. (https://doi.org/10.1016/s00225347(17)35636-7)

Ozturk U, Ozdemir E, Dede O, Sagnak L, Goktug HNG, Gurbuz OA, Cagatay M \& Imamoglu MA 2011 Assessment of anti-sperm antibodies in couples after testicular sperm extraction. Clinical and Investigative Medicine 34 E179-E183. (https://doi.org/10.25011/cim.v34i3.15191)

Pan L, Qiu D, Li J, Li J, Xu P, Zhao D \& Ma J 2016 Idiopathic male infertility in the Han population in China is affected by polymorphism in the VDAC2 gene. Oncotarget 7 82594-82601. (https://doi.org/10.18632/ oncotarget.12993)

Patel AS, Leong JY \& Ramasamy R 2018 Prediction of male infertility by the world health organization laboratory manual for assessment of semen analysis: a systematic review. Arab Journal of Urology 16 96-102. (https://doi.org/10.1016/j.aju.2017.10.005)

Perko Z, Rakić M, Pogorelić Z, Družijanić N \& Kraljević J 2011 Laparoscopic transabdominal preperitoneal approach for inguinal hernia repair: a fiveyear experience at a single center. Surgery Today 41 216-221. (https:// doi.org/10.1007/s00595-010-4266-4)

Petit FM, Serres C, Bourgeon F, Pineau C \& Auer J 2013 Identification of sperm head proteins involved in zona pellucida binding. Human Reproduction 28 852-865. (https://doi.org/10.1093/humrep/des452)

Pogorelić Z, Jurić I, Biočić M, Furlan D, Budimir D, Todorić J \& Milunović KP 2011 Management of testicular rupture after blunt trauma in children. Pediatric Surgery International 27 885-889. (https://doi.org/10.1007/ s00383-011-2873-9)

Prabha V, Gupta T, Kaur S, Kaur N, Kala S \& Singh A 2009 Isolation of a spermatozoal immobilization factor from Staphylococcus aureus filtrates. Canadian Journal of Microbiology 55 874-878. (https://doi. org/10.1139/w09-032)

Prabha V, Chaudhary N \& Kaur S 2011 Molecular mimicry between spermatozoa and bacteria. Journal of Urology 186 2442-2447. (https:// doi.org/10.1016/j.juro.2011.07.084)

Rabelo-Júnior CN, Freire De Carvalho J, Lopes Gallinaro A, Bonfá E, Cocuzza M, Saito O \& Silva CA 2012 Primary antiphospholipid syndrome: morphofunctional penile abnormalities with normal sperm analysis. Lupus 21 251-256. (https://doi.org/10.1177/0961203311422715)

Räsänen ML, Hovatta OL, Penttilä IM \& Agrawal YP 1992 Detection and quantitation of sperm-bound antibodies by flow cytometry of human semen. Journal of Andrology 13 55-64.

Rumke P 1954 The presence of sperm antibodies in the serum of two patients with oligospermia. Vox Sanguinis 4 135-140.

Rusz A, Pilatz A, Wagenlehner F, Linn T, Diemer T, Schuppe HC, Lohmeyer J, Hossain H \& Weidner W 2012 Influence of urogenital infections and inflammation on semen quality and male fertility. World Journal of Urology 30 23-30. (https://doi.org/10.1007/s00345-0110726-8)

Scarselli G, Livi C, Chelo E, Dubini V \& Pellegrini S 1987 Approach to immunological male infertility: a comparison between MAR test and direct immunobead test. Acta Europaea Fertilitatis 18 55-57.

Schachner M, Wortham KA, Carter LD \& Chaffee JK 1975 NS-4 (nervous system antigen-4), a cell surface antigen of developing and adult mouse brain and sperm. Developmental Biology 44 313-325. (https://doi. org/10.1016/0012-1606(75)90402-9)

Schlehofer JR, Boeke C, Reuland M \& Eggert-Kruse W 2012 Presence of DNA of adeno-associated virus in subfertile couples, but no association with fertility factors. Human Reproduction 27 770-778. (https://doi. org/10.1093/humrep/der427)

Schroeder Jr HW \& Cavacini L 2010 Structure and function of immunoglobulins. Journal of Allergy and Clinical Immunology $\mathbf{1 2 5}$ (Supplement 2) S41-S52. (https://doi.org/10.1016/j.jaci.2009.09.046)

Scott NW, McCormack K, Graham P, Go PM, Ross SJ \& Grant AM 2002 Open mesh versus non-mesh for repair of femoral and inguinal hernia. Cochrane Database of Systematic Reviews 4 CD002197. (https://doi. org/10.1002/14651858.CD002197)

Shibahara H, Shiraishi Y \& Suzuki M 2005 Diagnosis and treatment of immunologically infertile males with antisperm antibodies. Reproductive Medicine and Biology 4 133-141. (https://doi.org/10.1111/j.14470578.2005.00102.x)

Shinnick TM 1991 Heat shock proteins as antigens of bacterial and parasitic pathogens. Current Topics in Microbiology and Immunology 167 145-160. (https://doi.org/10.1007/978-3-642-75875-1_9)

Silverman GJ, Goodyear CS \& Siegel DL 2005 On the mechanism of staphylococcal protein A immunomodulation. Transfusion 45 274-280. (https://doi.org/10.1111/j.1537-2995.2004.04333.x)

Sinisi AA, Di Finizio B, Pasquali D, Scurini C, D'Apuzzo A \& Bellastella A 1993 Prevalence of antisperm antibodies by SpermMARtest in subjects undergoing a routine sperm analysis for infertility. International Journal of Andrology 16 311-314. (https://doi.org/10.1111/j.1365-2605.1993. tb01197.x)

Sousa AP, Amaral A, Baptista M, Tavares R, Caballero Campo P, Caballero Peregrín P, Freitas A, Paiva A, Almeida-Santos T \& Ramalho-Santos J 2011 Not all sperm are equal: functional mitochondria characterize a subpopulation of human sperm with better fertilization potential. PLOS ONE 6 e18112. (https://doi.org/10.1371/journal.pone.0018112)

Sršen D, Družijanić N, Pogorelić Z, Perko Z, Juričić J, Kraljević D, Krnić D, Bilan K \& Mimica Z 2008 Quality of life analysis after open and laparoscopic inguinal hernia repair: retrospective study. HepatoGastroenterology 55 2112-2115.

Štula I, Družijanić N, Sršen D, Čapkun V, Perko Z, Sapunar A, Kraljević D, Bošnjak N \& Pogorelić Z 2012 Influence of inguinal hernia mesh repair on testicular flow and sperm autoimmunity. Hernia 16 417-424. (https:// doi.org/10.1007/s10029-012-0918-1)

Štula I, Družijanić N, Sapunar A, Perko Z, Bošnjak N \& Kraljević D 2014 Antisperm antibodies and testicular blood flow after inguinal hernia mesh repair. Surgical Endoscopy 28 3413-3420. (https://doi. org/10.1007/s00464-014-3614-7)

Taiyeb AM, Ridha-Albarzanchi MT, Taiyeb SM, Kanan ZA, Alatrakchi SK, Kjelland ME \& Muhsen-Alanssari SA 2017 Improvement in pregnancy outcomes in couples with immunologically male infertility undergoing prednisolone treatment and conventional in vitro fertilization preceded by sperm penetration assay: a randomized controlled trial. Endocrine $\mathbf{5 8}$ 448-457. (https://doi.org/10.1007/s12020-017-1446-7)

Tiseo BC, Cocuzza M, Bonfá E, Srougi M \& Silva CA 2016 Male fertility potential alteration in rheumatic diseases: a systematic review. International Brazilian Journal of Urology 42 11-21. (https://doi. org/10.1590/S1677-5538.IBJU.2014.0595) 
van Weert JM, Repping S, van der Steeg JW, Steures P, van der Veen F \& Mol BWJ 2005 IUI in male subfertility: are we able to select the proper patients? Reproductive Biomedicine Online 11 624-631. (https://doi. org/10.1016/s1472-6483(10)61172-8)

Vazquez-Levin MH, Marín-Briggiler CI \& Veaute C 2014 Antisperm antibodies: invaluable tools toward the identification of sperm proteins involved in fertilization. American Journal of Reproductive Immunology 72 206-218. (https://doi.org/10.1111/aji.12272)

Veräjänkorva E, Laato M \& Pöllänen P 2003 Analysis of 508 infertile male patients in south-western Finland in 1980-2000: hormonal status and factors predisposing to immunological infertility. European Journal of Obstetrics, Gynecology, and Reproductive Biology 111 173-178. (https://doi.org/10.1016/s0301-2115(03)00312-9)

Verón GL, Molina RI, Tissera AD, Estofan GM, Marín-Briggiler CI \& Vazquez-Levin MH 2016 Incidence of sperm surface autoantibodies and relationship with routine semen parameters and sperm kinematics. American Journal of Reproductive Immunology 76 59-69. (https://doi. org/10.1111/aji.12519)

Wakimoto Y, Fukui A, Kojima T, Hasegawa A, Shigeta M \& Shibahara H 2018 Application of computer-aided sperm analysis (CASA) for detecting sperm-immobilizing antibody. American Journal of Reproductive Immunology 79 1-7. (https://doi.org/10.1111/aji.12814)

Wang MZ, Qiu ZL, Cai XS, Li JJ, She MQ, Xu YF \& Wu YS 2017 Secretory expression of a novel human spermatozoa antigen in E. coli and its application to a protein chip. Biotechnology Letters 39 1529-1535. (https://doi.org/10.1007/s10529-017-2377-3)

Weintraub S, Fahey C, Johnson N, Mesulam MM, Gitelman DR, Weitner BB \& Rademaker A 2006 Vasectomy in men with primary progressive aphasia. Cognitive and Behavioral Neurology 19 190-193. (https://doi. org/10.1097/01.wnn.0000213923.48632.ab)

Weng SL, Chiu CM, Lin FM, Huang WC, Liang C, Yang T, Yang TL, Liu CY, Wu WY, Chang YA et al. 2014 Bacterial communities in semen from men of infertile couples: metagenomic sequencing reveals relationships of seminal microbiota to semen quality. PLOS ONE 9 e110152. (https:// doi.org/10.1371/journal.pone.0110152)

Wick G, Knoflach M \& Xu Q 2004 Autoimmune and inflammatory mechanisms in atherosclerosis. Annual Review of Immunology 22 361-403. (https://doi.org/10.1146/annurev.immunol.22.012703.104644)

Wilson L 1954 Sperm agglutinins in human semen and blood. Proceedings of the Society for Experimental Biology and Medicine 85 652-655. (https://doi.org/10.3181/00379727-85-20982)

Witkin SS, Kligman I \& Bongiovanni AM 1995 Relationship between an asymptomatic male genital tract exposure to chlamydia trachomatis and an autoimmune response to spermatozoa. Human Reproduction 10 2952-2955. (https://doi.org/10.1093/oxfordjournals.humrep.a135827)

World Health Organization (WHO) 1992 WHO Laboratory Manual for the Examination of Human Semen and Sperm-Cervical Mucus Interaction, 3rd ed. Cambridge, UK: Cambridge University Press.

World Health Organization (WHO) 1999 WHO Laboratory Manual for the Examination of Human Semen and Sperm-Cervical Mucus Interaction, 4th ed. Cambridge, UK: Cambridge University Press.
World Health Organization (WHO) 2010 WHO Laboratory Manual for the Examination and Processing of Human Semen, 5th ed. Geneva, Switzerland: WHO Press.

Xu A, Hua Y, Zhang J, Chen W, Zhao K, Xi W, Wang H, Fang J, Su S, Tang M et al. 2016 Abnormal hypermethylation of the VDAC2 promoter is a potential cause of idiopathic asthenospermia in men. Scientific Reports 6 37836. (https://doi.org/10.1038/srep37836)

Xu F, Ye L, Hu Y, Cai C, Wang Z, Fan L, Song L, Xu Z \& Du W 2020 A novel protein biochip screening serum anti-sperm antibody expression and natural pregnancy rate in a follow-up study in Chinese infertility. Bioscience Reports 40 1-10. (https://doi.org/10.1042/BSR2 0191769)

Yasin AL, Yasin AL \& Basha WS 2016 The epidemiology of anti-sperm antibodies among couples with unexplained infertility in north west bank, Palestine. Journal of Clinical and Diagnostic Research 10 QC01QC03. (https://doi.org/10.7860/JCDR/2016/15788.7380)

Yeh WR, Acosta AA, Seltman HJ \& Doncel G 1995 Impact of immunoglobulin isotype and sperm surface location of antisperm antibodies on fertilization in vitro in the human. Fertility and Sterility $\mathbf{6 3}$ 1287-1292. (https://doi.org/10.1016/s0015-0282(16)57613-4)

Zamani MR, Asbagh FA, Massoud AH, Salmaninejad A, Massoud A \& Rezaei N 2015 Association between a PD-1 gene polymorphism and antisperm antibody-related infertility in Iranian men. Journal of Assisted Reproduction and Genetics 32 103-106. (https://doi.org/10.1007/ s10815-014-0371-4)

Zini A \& Sigman M 2009 Are tests of sperm DNA damage clinically useful? Pros and cons. Journal of Andrology 30 219-229. (https://doi. org/10.2164/jandrol.108.006908)

Zini A, Phillips S, Lefebvre J, Baazeem A, Bissonnette F, Kadoch IJ \& Gabriel MS 2010 Anti-sperm antibodies are not associated with sperm DNA damage: a prospective study of infertile men. Journal of Reproductive Immunology 85 205-208. (https://doi.org/10.1016/j. jri.2010.03.006)

Zini A, Fahmy N, Belzile E, Ciampi A, Al-Hathal N \& Kotb A 2011a Antisperm antibodies are not associated with pregnancy rates after IVF and ICSI: systematic review and meta-analysis. Human Reproduction 26 1288-1295. (https://doi.org/10.1093/humrep/der074)

Zini A, Lefebvre J, Kornitzer G, Bissonnette F, Kadoch IJ, Dean N \& Phillips S 2011b Anti-sperm antibody levels are not related to fertilization or pregnancy rates after IVF or IVF/ICSI. Journal of Reproductive Immunology 88 80-84. (https://doi.org/10.1016/j.jri.2010. 09.002)

Received 23 March 2021

First decision 25 May 2021

Revised manuscript received 24 June 2021

Accepted 30 July 2021 